\title{
MANDATO POLICIAL NA PRÁTICA: tomando decisões nas ruas de João Pessoa
}

\author{
Jacqueline de Oliveira Muniz \\ Washington França da Silva*
}

\begin{abstract}
Este artigo volta-se para o chamado modus operandi dos patrulheiros da ordem pública da Polícia Militar da Paraíba, dirigindo o seu olhar para o que seja o "padrão operacional" dos PMs que fazem o "policiamento ostensivo" em João Pessoa. Toma como percurso o ponto de vista desses policiais sobre a sua práxis discricionária no atendimento às ocorrências criminais e não-criminais, buscando compreender como o mandato público de polícia se faz nas ruas e, por conseguinte, com que meios e modos a autoridade policial é concretamente exercida diante dos "fins" para os quais ela é chamada a atuar.

PALAVRAS-CHAVE: mandato policial, poder discricionário, Polícia Militar, administração de conflitos, uso da força.
\end{abstract}

\section{INTRODUÇÃO}

O que faz a polícia nas ruas diante do seu mandato? Como os policiais, na prática, empregam o "poder de polícia” a eles delegado? De que forma decidem quando e como atuar nos eventos que são chamados a intervir? Que fatores conformam, aqui nas esquinas de nossas cidades, as decisões e as soluções policiais produzidas? Em que consiste a práxis discricionária nas atividades de policiamento público estatal?

Essas são algumas indagações que estruturaram o campo de estudos policiais e que seguem sendo fundamentais para o entendimento das polícias e das práticas de policiamento em sociedades democráticas. Todas elas incidem sobre um ponto

* Antropóloga. Doutora em Ciência Política pelo IUPERJ, Universidade Candido Mendes - UCAM. Professora do Mestrado em Direito da UCAM e da Graduação Tecnológica em Segurança e Ordem Pública (TECSOP) da Universidade Católica de Brasília - UCB.

Universidade Católica de Brasília. Qs 07, lote 01, epct, Bl. M sala 209 - Águas Claras - Taguatinga. Cep: 71966-700 Brasília, DF-Brasil. jacquelinedeoliveira.muniz@gmail.com

* * Oficial da Polícia Militar do Estado da Paraíba, especialista em políticas públicas de justiça criminal e segurança pública e associado do Fórum Brasileiro de Segurança Pública.germanofranca@uol.com.br central: o poder de produção de alternativas legais e legítimas de obediência a uma dada ordem pactuada sob o império da lei, e o uso discricionário desse poder em sociedades livres e plurais. É o mandato do uso potencial e concreto de força, ou os meios e modos utilizados diante dos fins estabelecidos pela sociedade policiada e seu governo, que têm circunscrito o estado da arte da produção científica sobre as práticas de policiamento, a construção negociada de enforcement [imposição da lei] e os atores autorizados a exercê-las.

Skolnick (1994 [1966]) caracteriza o dilema entre lei e ordem como estruturante do fazer policial nas sociedades democráticas, situando a discricionariedade como práxis policial. Wilson (1968), a partir da oposição "law enforcement versus order maintenance" [imposição da lei versus manutenção da ordem], constrói uma tipologia de comportamentos policiais "watchman style", "service style" e "legalistic style" - [o "vigilante", o "prestador de serviços" e o "legalista"] para circunscrever os fatores determinantes da discricionariedade e a extensão do seu uso nas respostas produzidas pela 
polícia. Goldstein (2003 [1977]), de posse da evidência de que a polícia exerce um amplo poder discricionário, indica rumos para o seu controle pelo governo e pela sociedade, categorizando e estruturando o que seja esse poder. Muir Jr. (1977) constrói tipos ideais de "personalidades policiais”, de inspiração weberiana, explorando a natureza política da coerção e os "paradoxos" do seu exercício, com base em uma etnografia das interações entre policiais e cidadãos. Klockars (1985), a partir do que seja a "ideia de polícia" na democracia, retoma as perspectivas de Goldstein e Muir Jr. acerca da discricionariedade, caracterizando a natureza seletiva do enforcement policial e avaliando os modelos policiais de aplicação seletiva da lei. Bayley ([1985] 2001), por meio de uma perspectiva comparada sobre a evolução, a função e a política das polícias no mundo moderno, propõe uma "teoria do policiamento" que ambiciona compreender os diversos mecanismos e arranjos de controle social que, de alguma maneira, possuem "poder de polícia".

Todas essas perspectivas, seja quando se ocupam de compreender aspectos do trabalho policial, funções ou práticas policiais historicamente enraizadas, seja quando pretendem conceituar o lugar de polícia, sua natureza e atributos essenciais, dialogam de maneira mais ou menos direta com a proposta de Bittner ([1974] 1990) de uma teoria de polícia. O núcleo duro dessa teoria, esboçada inicialmente em 1971, é a conceituação do mandato policial expressa na proposição de que "The policeman, and the policeman alone, is equipped, entitled, and required to deal with every exigency in which force may have to be used, to meet it." (Bittner, [1974], 1990, p.256, ênfases no original). ${ }^{1}$

O policial é equipado tanto em termos de meios quanto de modos para o agir decisivo no cumprimento do seu mandato. Está autorizado porque lhe são concedidos respaldo legal e consentimento social para policiar. E responde por

${ }^{1}$ Tradução livre: "O policial, e apenas o policial, está equipado, autorizado e é requerido para tratar com toda a exigência em que a força possa ter de ser usada para enfrentá-la" qualquer exigência, qualquer evento ou conflito que ameace um dado status quo, cuja amplitude corresponde à paz social pactuada entre a sociedade e seu governo.

Para Muniz e Proença Jr. (2007a, p.233), a proposta conceitual de Bittner supera o clássico dilema entre lei e ordem, restituindo a totalidade do trabalho policial pela incorporação de duas dimensões empíricas essenciais: "o que se espera que a polícia faça” e "o que ela de fato faz". Tal integralidade torna-se possível, uma vez que Bittner "identifica o uso da força como o atributo comum que articula as expectativas sociais em tudo que a polícia é chamada a fazer e o conteúdo substantivo de tudo que a polícia faz". É dessa maneira que a teoria de Bittner reconstitui a plenitude do mandato policial, conceituando "o que a polícia é".

É porque a polícia está autorizada a usar de força, e se espera que ela o faça sempre que isso seja necessário, que ela é chamada a atuar quando "algo que não deveria estar acontecendo está acontecendo e alguém deve fazer algo a respeito agora" (Bittner, [1974], 1990 p.249, ênfases no original). Isso revela porque a polícia pode atender a emergências, respaldar a lei, sustentar a ordem pública, preservar a paz social, mediar conflitos, auxiliar, assistir, advertir, socorrer, dissuadir, reprimir ou desempenhar quaisquer outras funções sociais de forma reativa ou preemptiva. Esclarece porque as polícias executam as mais diversas formas ou padrões de policiamento. Explica por que a polícia é chamada a atuar, e deve fazê-lo em todas as situações em que a força possa ser útil. Enfim, possibilita compreender a "decisividade" no fazer policial, sua medida de autonomia decisória, sua discricionariedade para produzir soluções legais e legitimas, porém provisórias, para problemas inadiáveis no tempo mesmo de sua ocorrência.

Mas como se dá esta decisividade policial ali, quando os policiais "encontram com as ocorrências" ou são "chamados" pelos cidadãos até elas? Como os policiais decidem à luz das exigências do seu mandato e diante das expectativas e representações sociais do seu trabalho? Como se "tira polí- 
cia” ou se faz "valer a autoridade do polícia"? De que maneira sua competência decisória é, de fato, exercida no "calor dos acontecimentos"?

Este artigo volta-se para o chamado modus operandi dos patrulheiros da ordem pública da Polícia Militar da Paraíba, dirigindo o seu olhar para o que seja o "padrão operacional" dos PMs que fazem o "policiamento ostensivo" em João Pessoa. Toma como percurso o ponto de vista desses policiais sobre a sua práxis discricionária no atendimento às ocorrências criminais e não-criminais, situando os fatores que eles identificam como complicadores na condução desses eventos e de que maneira constroem o lugar de sua "autoridade".

\section{O CAMPO: um outro de nós mesmos}

O retrato descritivo e exploratório aqui apresentado sobre como os PMs caracterizam a sua decisividade - navegando entre o legal, o legítimo, o politicamente respaldado e tolerado socialmente - tem como base empírica alguns resultados de um estudo de caso sobre a natureza do trabalho da polícia ostensiva, realizado com os policiais militares da Paraíba empregados no policiamento da cidade de João Pessoa. ${ }^{2}$ Este estudo teve como objetivo primeiro verificar como esses agentes da lei e da ordem, no uso dos seus mandatos, atendem e administram as ocorrências criminais de menor potencial ofensivo e as não-criminais. ${ }^{3}$

Além dos levantamentos bibliográfico e

${ }^{2}$ A pesquisa foi desenvolvida, no período de março a novembro de 2009 , com os profissionais direta ou indiretamente envolvidos com a gestão das ocorrências policiais: os do Centro Integrado de Operações Policiais - central de atendimento emergencial da polícia - e, principalmente, os lotados no $1^{\circ}$ e no $5^{\circ}$ Batalhões de Polícia Militar, que trabalham exclusivamente no patrulhamento das ruas ao todo 739 policiais militares -, atividade exercida massivamente por praças (sargentos, cabos e soldados), personagens principais deste estudo.

${ }^{3}$ Realizado pelo Cel PM Washington França da Silva, sob a orientação da Prof ${ }^{a}$ Dra. Jacqueline de Oliveira Muniz, esse trabalho monográfico, intitulado "Políticas, procedimentos e práticas da polícia ostensiva no atendimento às ocorrências criminais de menor potencial ofensivo e as nãocriminais: umm estudo sobre a atuação da Polícia Militar da Paraíba em João Pessoa”, foi apresentado, em dezembro de 2009, ao Centro de Altos Estudos de Segurança da Polícia Militar do Estado de São Paulo, para cumprir o requisito de conclusão do Curso Superior de Polícia, tendo sido avaliado e aprovado pela banca examinadora com- documental, durante a realização do trabalho de campo, foram aplicados questionários ${ }^{4}$ e entrevistas individuais e coletivas a boa parte desse contingente policial, o que resultou numa amostra de 156 questionários válidos ${ }^{5}$ e 40 entrevistas. Além disso, também foram realizadas entrevistas com representantes do Ministério Público, delegados de polícia civil das delegacias distritais existentes na área de estudo, comandantes das unidades e subunidades de polícia militar, docentes das escolas de formação e aperfeiçoamento dos policiais militares e com representantes das comunidades, beneficiários do serviço prestado por esses policiais fardados.

Especialmente nas entrevistas com os policiais militares responsáveis pelo patrulhamento das ruas, buscou-se criar um ambiente de descontração, de informalidade, de bate-papo, deixando-os livres para se manifestar, para que pudessem, espontaneamente, falar sobre a natureza do seu trabalho. Nessas conversas, a atenção estava voltada para conhecer um pouco mais sobre suas práticas profissionais, as formas utilizadas para interpretar e resolver as diversas situações de conflito e violência social. Esses depoimentos livres foram também oportunos para se conhecer o dilema quanto aos limites dessa intervenção, bem como as dificuldades enfrentadas por esses policiais para desempenharem suas atividades.

Sem dúvida, entrevistar os policiais foi um dos momentos mais importantes do estudo, sobretudo pelo seu caráter interativo e pela rique-

posta por: Prof ${ }^{a}$ Dra. Jacqueline de Oliveira Muniz (Universidade Cândido Mendes), Prof ${ }^{\circ}$ Dr. Renato Sérgio de Lima (Fórum Brasileiro de Segurança Pública), Prof ${ }^{\mathrm{a}}$ Dra. Haydée Caruso (Secretaria Nacional de Segurança Pública), Cel PM José Vicente da Silva (Polícia Militar do Estado de São Paulo) e Maj PM Azor Lopes da Silva Júnior (Polícia Militar do Estado de São Paulo).

${ }^{4}$ Os questionários com questões fechadas, destinado exclusivamente aos policiais do patrulhamento de rua, foram aplicados por três policiais femininas devidamente capacitadas. O objetivo da escolha de policiais femininas como entrevistadoras foi o de, contando com sua maior sensibilidade e, portanto, maior poder de persuasão, ampliar o trabalho da amostra e evitar qualquer sentimento de obrigatoriedade por parte dos entrevistados ao responder o questionário. Também para impedir qualquer resultado tendencioso, foram selecionadas policiais que não trabalhavam no policiamento.

${ }^{5}$ Correspondente a $21,1 \%$ do contingente de policiais militares empregado no patrulhamento das ruas. 
za de informações a que se teve acesso, o que possibilitou uma interpretação mais sensível dos dados obtidos por meio dos questionários.

De início, poderia parecer impossível a um policial, sobretudo pela sua condição de superior hierárquico dos entrevistados, realizar um estudo dessa natureza. Pois bem, para superar essa limitação inicial, foi preciso transpor a barreira hierarquizada da comunicação que, culturalmente, faz parte das relações entre oficiais e praças das Polícias Militares do Brasil. Aqui, cabe um relatotestemunho de um dos autores, o Coronel PM Washington, um oficial tido como "boa praça", a quem coube a condução das atividades de campo:

Devidamente autorizado pelo Comando da Corporação, assumindo a condição de aluno-pesquisador, na maioria dos contatos com esses policiais, literalmente, me despi do uniforme e procurei estabelecer uma relação horizontal, baseada na confiança, no respeito, na verdade e na sinceridade. Apoiei-me no fato de que, em algum nível, falávamos a mesma língua, a do policial militar que jurou "servir e proteger" a população. Afinal, "todo polícia calça 40", como se diz no interior das casernas. A minha disposição de ouvi-los ia ao encontro da sua necessidade de falar, de compartilhar as dificuldades e, até mesmo, desabafar, numa verdadeira catarse, que contava sem meias palavras, "o lado do PM" que "tira polícia", o lado das ruas, um lado bem diferente daqueles oficiais que só serviriam para "canetar o PM".

Confesso que muitas vezes me emocionei, vendo-me entre eles, um pouco como eles, um pouco com um "outro" de "nós". Este lugar de descobertas e de mútua identificação foi também favorecido pelo fato de ser percebido pelos praças como um Oficial "diferente", um Coronel "moderno", sem "militarismos", que "vê os direitos humanos dos PMs".

Tudo isso só reforçou minhas convicções e consolidou o meu respeito a esses profissionais. Foi, verdadeiramente, um importante exercício de diálogo, se constituindo num grande aprendizado sobre o fazer polícia nas ruas.

\section{QUEM SÃO OS PMS DE RUA DE JOÃO PESSOA}

No Brasil, conforme estabelece o $\S 5^{\circ}$ do Art.144 da Constituição Federal, o trabalho de polícia ostensiva e de preservação da ordem pública é da competência exclusiva das polícias militares, instituições estaduais integrantes do sistema de segurança pública (Brasil, 2007).
A Polícia Militar do Estado da Paraíba (PMPB), ${ }^{6}$ em particular, conta, hoje, segundo informações da sua Diretoria de Gestão de Pessoas, com 9.230 policiais militares, sendo 673 oficiais e 8.557 praças. Esses efetivos estão distribuídos nos seus diversos órgãos de direção estratégica e setorial, de execução e vinculados, para assistir a uma população, segundo estimativa do Instituto Brasileiro de Geografia e Estatística (IBGE) para o ano de $2010,{ }^{7}$ de aproximadamente 3.753 .633 habitantes, distribuída nos 223 municípios que compõem o território paraibano.

A capital, João Pessoa, recorte geográfico da pesquisa, está incluída nas áreas de atuação de duas unidades operacionais, o $1^{\circ}$ e o $5^{\circ}$ Batalhões de Polícia Militar, os quais contavam, então, respectivamente, com um efetivo de 489 e 250 homens e mulheres, totalizando um contingente de 739 policiais militares para pronto-emprego no policiamento ostensivo dos 62 bairros e 101 comunidades aglomeradas, onde moravam, segundo estimativa populacional do IBGE/2009, ${ }^{8}$ 702.235 habitantes. Habitantes, ${ }^{9}$ ocupando uma área territorial de $211 \mathrm{~km}^{2}$. As modalidades mais destacadas da atividade-fim desenvolvidas por essas duas unidades operacionais são a patrulha a pé, a patrulha motorizada de auto (mais conhecida como RP ou radiopatrulhamento), o motopatrulhamento ou patrulhamento com moto e a ciclopatrulha ou patrulha de bicicleta.

Em relação à identidade social desses policiais militares (PMs) que policiam as ruas de João

${ }^{6}$ Conforme estabelece o Inciso II do Art. $4^{\circ}$ da Lei Complementar n⿳0 87/2008, compete à Polícia Militar da Paraíba "executar com exclusividade, ressalvadas as missões peculiares às Forças Armadas, o policiamento ostensivo fardado para prevenção e repressão dos ilícitos penais e infrações definidas em lei, bem como as ações necessárias ao pronto restabelecimento da ordem pública.” (Paraíba, 2008).

${ }^{7}$ Ver dados do Censo Demográfico de 2010 disponíveis no site do IBGE e publicados no Diário Oficial da União do dia $04 / 11 / 2010$, na Resolução $n^{\circ} 6$, de 3 de novembro de 2010 (IBGE, 2010b).

${ }^{8}$ Ver o site do IBGE Cidades@ (IBGE, 2010c). Hoje, a população de João Pessoa, segundo o Censo Demográfico 2010 , é de 716.042 (setecentos e dezesseis mil e quarenta e dois) habitantes (IBGE, 2010b).

${ }^{9}$ A relação dessa população residente em João Pessoa com o contingente policial empregado pelas duas unidades operacionais responsáveis pelo policiamento das ruas dessa cidade para proteger essa mesma população é de aproximadamente 950 hab/PM. 
Pessoa, a pesquisa revelou que se trata de um universo composto majoritariamente por homens (94\%), integrantes do círculo hierárquico dos praças - sargentos, cabos e soldados (96\%). ${ }^{10} \mathrm{Na}$ sua maioria, são jovens (68\% têm, no máximo, 40 anos de idade), paraibanos (88,9\%) e nascidos na capital $(64,7 \%)$. Possuem o ensino médio completo $(80,4 \%),{ }^{11}$ declaram-se casados $(55,8 \%)$ e 84,1\% têm até três filhos. A maior parte deles possui uma renda familiar de até cinco salários mínimos $(77,1 \%)$, e se apresenta como o principal responsável pelo provimento familiar $(66,4 \%)$. Os PMs relatam ainda que são católicos $(64,5 \%){ }^{12}$ Eles formam um contingente de mestiços - pardo, moreno ou mulato $(64,3 \%)-$, que integram a Corporação há pelo menos dez anos (55,5\%), possuindo, no máximo, cinco anos de experiência no patrulhamento das ruas $(47,5 \%)$. São esses, portanto, os profissionais que estão diuturnamente nas ruas da cidade de João Pessoa atendendo aos diversos chamados da população: homens e mulheres, oriundos das classes populares, que começaram a trabalhar ainda quando eram adolescentes, e que viram na PMPB uma oportunidade de “entrar para o serviço público" e, com isso, alcançar a estabilidade e a ascensão social desejadas.

\section{CHAMANDO A PM: ocorrências em númerose relatos}

Dizem que, no futebol, a bola sempre procura o craque, o bom atacante. Pois, para os PMs

${ }^{10}$ Esse percentual é compatível com a distribuição hierárquica do efetivo da Corporação, em que os oficiais representam apenas $7,3 \%$ do número total de policiais militares e os praças, $92,7 \%$ desse mesmo número total.

${ }^{11}$ Desses, 26,1\% têm formação educacional superior. Apesar de a exigência do ensino médio para ingresso na Polícia Militar da Paraíba ter sido estabelecida desde o ano de 1999, verifica-se que $19,6 \%$ desses policiais militares não têm essa escolarização, o que aponta para a inexistência de uma política de elevação da escolaridade na Corporação.

12 Também 23,2\% se declararam evangélicos. Comparando esses percentuais da amostra com os dados do Censo do IBGE (2000), em que $84,9 \%$ dos paraibanos se disseram católicos e $8,8 \%$ evangélicos, constata-se que, no universo pesquisado, embora os católicos sejam grande maioria, é perceptível o crescimento do número de evangélicos, inclusive com um percentual maior do que da população como um todo. da ordem pública de João Pessoa, acontece algo parecido: as ocorrências sempre correm atrás dos policiais, e não há (muito) como fugir delas. Responsáveis por "servir e proteger o cidadão", os policiais da ponta da linha são, diuturnamente, empregados na execução do policiamento ostensivo. No jargão profissional, encontram-se "a postos", "de prontidão" ou no "pronto-emprego" para atender a todo tipo de chamada da população, o que vai do crime em andamento, passando pelo bate-boca entre vizinhos, até a prosaica retirada do gato do telhado.

Do interior de suas viaturas, eles caminham entre "empenhos", de uma chamada emergencial a outra, para intervir em 'algo que não deveria estar acontecendo [e que] está acontecendo e [que] alguém deve[rá] fazer algo a respeito agora'. (Bittner, [1974], 1990 p.249, ênfases no original). Eles estão sempre por aí, entre nós e os outros. Pelas ruas e grotões da cidade, para assistir, fazendo uso dos significados correntes que essa palavra encerra: fazer-se presente ou ostensivo, ajudar e dar razão a alguém, antes, durante e depois das dramatizações cotidianas do pior de nós mesmos.

Um retrato ampliado da realidade dos chamamentos à PM pode ser extraído do universo de ligações, despachos e eventos atendidos pelo Centro Integrado de Operações Policiais (CIOP) da Secretaria de Estado da Segurança e da Defesa Social da Paraíba (SEDS-PB), que funciona 24 horas por dia, encaminhando as chamadas emergenciais. Na capital, entre os anos de 2007 e 2008, a média diária de chamadas para a linha 190 foi de 2.516 ligações telefônicas. Dessas, apenas $10 \%$ resultaram em ocorrências atendidas e notificadas como "não-criminais" e "criminais de maior e menor potencial ofensivo". Para que se possa compreender o uso dessas categorias na práxis policial, cabe fazer um breve parêntesis para, de forma sucinta, apresentar o seu conteúdo jurídico-policial.

A lógica-em-uso pela polícia de tradução instrumental dos atos praticados pelos cidadãos em fatos com rendimento policial e jurídico, tem como 
referência primeira os marcos legais em vigor, especialmente a legislação penal. No processo interpretativo de convergência entre as leis do mundo e o mundo da lei, as ocorrências classificadas como "criminais" são aquelas que mais diretamente encontram uma correspondência com os tipos penais previstos em nosso ordenamento jurídico.

De acordo com Capez (2007), tomando como critério ordenador o "potencial ofensivo" dos eventos, tem-se que as ocorrências criminais de maior potencial ofensivo são aquelas infrações penais de natureza grave, mas que não são definidas como crimes hediondos. As ocorrências criminais de menor potencial ofensivo, conforme a Lei 9.099/95, ${ }^{13}$ reportam-se às contravenções penais e aos crimes "... a que a lei comine pena máxima não superior a 2 (dois) anos, cumulada ou não com multa” (Brasil, 2007, p.765). Quanto às ocorrências não-criminais, elas podem ser definidas como aquelas condutas humanas que não estão tipificadas criminalmente, mas que geram disputas ou conflitos, podendo vir a expressar um potencial violento ou criminal.

Ao se organizarem as chamadas que se converteram em atendimentos registrados pelos policiais segundo seu potencial ofensivo, tem-se uma interessante revelação. Conforme se verifica no Gráfico 1, os PMs que patrulham as ruas de João Pessoa são mais chamados pela população para resolver, primeiramente, as ocorrências clas- sificadas como não-criminais (44\%), seguidas das criminais de menor potencial ofensivo (31\%) e, por último, as criminais de maior potencial ofensivo $(25 \%)$.

Constata-se que parte expressiva das ocorrências que resultaram em alguma intervenção policial notificada, cerca de $75 \%$, não diz respeito aos chamados grandes delitos, que mobilizam as expectativas e representações do senso comum e dos próprios policiais sobre o verdadeiro trabalho de polícia de "combater a criminalidade violenta, os 'bandidos de carreira' que ameaçam a sociedade". Ao contrário, o que a base de dados oficiais do CIOP/SEDS-PB aponta é que a maior parte do tempo dos praças da PMPB é gasta dando conta de conflitos, incivilidades, desordens, violações de direitos e pequenos delitos. Enfim, incidentes e acidentes perpetrados por cidadãos comuns que conformam a gestão cotidiana disso que nomeamos como a ordem pública.

Em um recorte mais desagregado dos dados oficiais por tipo individualizado de ocorrência, tem-se que as cinco categorias mais notificadas do sistema classificatório da Polícia Militar são: (i) averiguação de pessoa(s) em atitude suspeita $(18,5 \%)$; (ii) assalto ou furto (16\%); (iii) pessoa(s) embriagada(s) ou drogada(s) praticando desordem (11,6\%); (iv) acidente de trânsito sem vítima (8,9\%); e (v) ameaça (7\%). Note-se que, excluindo os crimes de rua mencionados

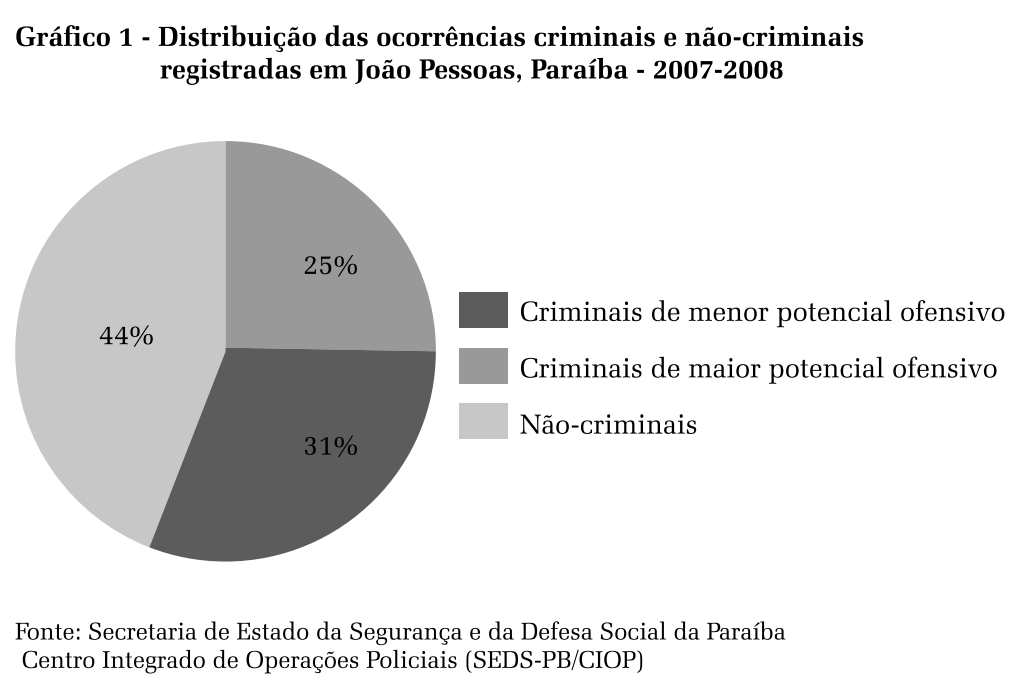

${ }^{13}$ A Lei 11.313, de 28 de junho de 2006, alterou a redação do art. 61 da Lei 9.099, de 26 de setembro de 1995 , ampliando o conceito das infrações penais de menor potencial ofensivo, anteriormente modificado pela Le 10.259, de 12 de julho de 2001 (Brasil, 2006). Ainda sobre essa lei, o seu art. 69 instituiu a figura jurídica do Termo Circunstanciado - registro qualificado das partes envolvidas numa ocorrência de menor potencial ofensivo -, o qual deve ser lavrado pela autoridade policial e encaminhado aos Juizados Especiais Cíveis e Criminais, instâncias competentes, segundo também define o art. 60 dessa mesma lei, para realizar “... a conciliação, o julgamento e a execução das infrações penais de menor potencial ofensivo.“
(Brasil, 2007, p.765).
Centro Integrado de Operações Policiais (SEDS-PB/CIOP) 
(assalto e furto), classificáveis como tipos criminais de maior potencial ofensivo, os demais fazem parte da miríade de eventos enquadrados como tipos criminais de menor potencial ofensivo e não-criminais.

Essa realidade, em números, conflita com a percepção dos 156 sargentos, cabos e soldados que responderam ao questionário da pesquisa. Para os nossos entrevistados, parte significativa do seu tempo, algo como $81 \%$, é mobilizado no atendimento às situações propriamente criminais, de menor potencial ofensivo (45\%) e de maior potencial ofensivo (36\%). Já as ocorrências não-criminais - que, de acordo com as informações do CIOP/SEDS-PB, ocupam o primeiro lugar das chamadas atendidas e registradas aparecem na hierarquia estabelecida pelos policiais em terceiro lugar, com 19\% das respostas válidas, tal como ilustra o Gráfico 2.

Uma vez indagados sobre os cinco tipos individualizados de ocorrências em que eles mais atuam, quatro das situações mais lembradas são categorizadas pela PMPB como criminais: (i) assalto ou furto (19,4\%); (ii) agressão física com e sem ferimento ou lesão (11,4\%); (iii) ameaça (9,6\%); e (iv) pessoa(s) embriagada(s) ou drogada(s) praticando desordem (7,1\%). Desse conjunto de respostas obtidas, apenas uma ocorrência de tipo não-criminal, atrito verbal, discussão ou bate-boca $(8,8 \%)$, foi mencionada.
Os representantes comunitários que atuam nas áreas de policiamento cobertas pelos PMs entrevistados compartilham da mesma percepção ampliada acerca da incidência e gravidade dos eventos criminais em suas comunidades. Quando perguntados sobre as situações em que a PM é mais chamada na sua vizinhança, a maioria das lideranças comunitárias (73\%) apontou as situações criminais de maior potencial ofensivo como as mais frequentes, seguidas das criminais de menor potencial ofensivo (24\%) e, por último, as situações não-criminais (3\%), essas últimas mencionadas de maneira pouco significativa. Do seu ponto de vista, são os eventos interpretados como a criminalidade - assaltos, homicídios, desordem, confusão, briga, tráfico de drogas e furtos - que mais produzem medo e insegurança, motivando os moradores a chamar a polícia.

Entre números e relatos, identifica-se uma inversão simétrica das representações sobre a incidência dos eventos que ordenam o atendimento policial em João Pessoa. A narrativa extraída dos registros policiais contrasta com as alegorias discursivas vocalizadas pelos PMs e pelos portavozes de sua imediata clientela. A serviço de lógicas distintas de fabricação do real, a verdade dos números contraria a verdade ambicionada pelos relatos dos policiais e lideranças comunitárias, conforme é visualizado na Figura 1.

A seletividade do

Gráfico 2 - Distribuição das situações para as quais a PM é chamada, por potencial ofensivo, segundo os policiais. Município de João Pessoa, Paraíba - 2009

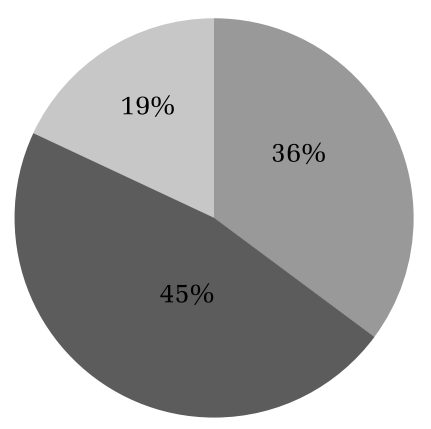

Criminais de menor potencial ofensivo

Criminais de maior potencial ofensivo

Não-criminais

Fonte: Silva, W. (2009) mundo dos números indica que não são os chamados grandes delitos que mais mobilizam o trabalho do policial de rua, como enuncia a seletividade das percepções dos PMs e dos líderes comunitários, e, sim, as ocorrências não-criminais e criminais de menor potencial ofensivo. São, por um lado, os pequenos delitos, e, por outro, os conflitos, as práticas desordeiras e inciviliza- 
Figura 1 - Representação da incidência das ocorrências policiais segundo os registros no CIOP/SEDS-PB e as percepçóes dos PMs e lideranças comunitárias,

em João Pessoa, 2008-2009

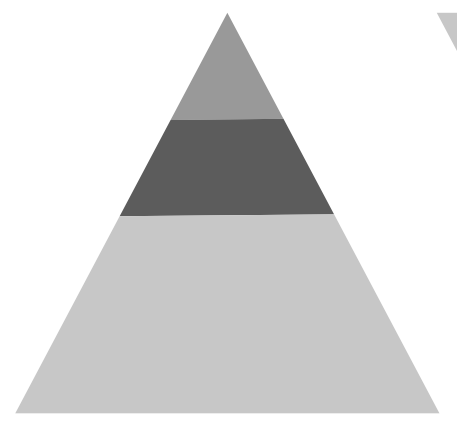

Ocorrências registradas

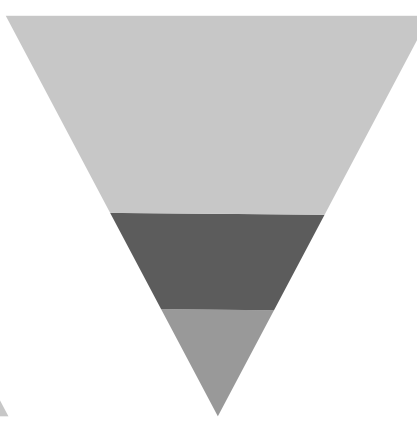

Percepções
Criminais de menor potencial ofensivo

Criminais de maior potencial ofensivo

Não-criminais

Fonte: Silva, W. (2009)

das, as quais não encontram tradutibilidade na sintaxe jurídico-penal e possuem pouco rendimento para a linha de produção do sistema de justiça criminal, que mais mobilizam a população paraibana a acionar a polícia. São aqueles eventos cotidianos, violentos ou não, nos quais qualquer um pode se envolver ou vir a estar exposto, que respondem pela maioria dos problemas de insegurança em João Pessoa.

Essa disparidade tem sua razão de ser. Resguardadas as especificidades culturais, políticas e legais da administração da segurança pública em grupos sociais, localidades, regiões ou mesmo países distintos, identificam-se padrões aproximados de atendimento policial, tal como retratado por Skolnick ([1966] 1994) e Bittner ([1974] 1990) nos Estados Unidos, por Bayley (1991) no Japão, por Reiner (1992) na Inglaterra e por Muniz (1999) no Rio de Janeiro, Brasil. Os estudos desses autores, com distintos recortes empíricos e teóricos, problematizam o mito do "verdadeiro trabalho policial", caracterizado como o enfrentamento do grande crime. E esclarecem que essa crença disseminada na vida ordinária, entre policiais e po- pulares, possui várias serventias. Trata-se de uma espécie de meia-verdade, um "dourar de pílula", rentável simbolicamente, que atende a estratégias de legitimação, seja para mobilizar a atenção prioritária da polícia no atendimento às demandas, seja para emprestar reconhecimento público ao próprio trabalho policial, frequentemente confinado ao trato com pessoas, acontecimentos e coisas comuns, ordinários e de baixa notabilidade. Policiais e cidadãos, egressos do mundo dos simples mortais em sua maioria, sabem que o fato de caracterizar e espetacularizar os eventos como "grandes crimes", altamente perigosos e violentos, instrumentalizando a gramática do medo, permite tentar "furar a fila" das prioridades das autoridades, da chamada "sociedade”, da mídia e da própria polícia, em relação aos seus problemas e demandas. As pesquisas de Manning (1988) e de Waddington (1993) sobre os significados das chamadas e respostas da polícia revelam que os cidadãos, por exemplo, para forçar um atendimento policial mais rápido, costumam exagerar os relatos, "criminalizando" os eventos que noticiam. Os policiais, por sua vez, fazem uso do mesmo expediente discursivo para sobrevalorizar suas atuações, colorindo a opacidade de seu cotidiano profissional com as tintas fortes e vibrantes do enfrentamento do grande crime e da violência.

Tudo isso porque os pequenos fatos que constroem a ordem pública, apesar de gerarem os grandes problemas de insegurança, possuem baixa visibilidade social, fazendo parte das estórias legítimas de pessoas comuns, e não das histórias legitimadas pelos registros. Por tudo isso, são exatamente as pequenas ocorrências criminais de menor potencial ofensivo e não-criminais que ordenam o dia a dia da polícia ostensiva e desafiam a compreensão dos processos decisórios policiais. 
PADRÕESDE TOMADA DE DECISÃO POLICIAL NAS RUAS: a "tal" da discricionariedade em ato

Proteger a sociedade não é uma missão fácil. Ela mexe muito com a "cabeça" dos PMs. Um dia sim outro também, eles são instados a intervir no imediato da ordem moral das coisas, interpondo-se entre nossas paixões e apetites, inscrevendo-se entre vontades em oposição ou interesses em conflito. Os policiais ostensivos estão ali, na fronteira mesma entre o direito de todos, os direitos dos outros e os nossos direitos, (re) colocando a cerca, mais uma vez e de novo, entre as partes e suas mais (in)acreditáveis "razões". Nos cruzamentos e colisões de nossas trajetórias, situam-se como um tipo de alter ego político, um streetcorner politician [político da esquina], como quer Muir Jr. (1977) que faz "valer a autoridade", alguma autoridade, para tratar com a alteridade, procurando dar um encaminhamento ao que se manifesta como volátil, dissimulado, humilhante, violento, difuso, vulnerável, trágico, cômico e frequentemente patético de nossa existência.

Não parece mesmo fácil preservar a (tal da) ordem pública. Na condição de cidadãos, as pessoas podem sempre se encontrar com razão de mais ou de menos, com direito de mais ou de menos, necessitando da presença da autoridade policial para dar um destino à sua situação. Por isso, todo assunto pode vir a dar "assunto para a polícia”, se assim querem os cidadãos, se assim querem o policiais, que reconhecem, na conduta das partes, algo que deve e pode ser transformado em um "caso de polícia".

Estes quereres exprimem níveis de discricionariedade que se manifestam no exercício do mandato policial. ${ }^{14} \mathrm{O}$ primeiro deles, e o mais relevante, é a discricionariedade dos cidadãos que, exterior à polícia, conforma a sua alocação, quando decidem, por exemplo, se cha-

\footnotetext{
14 Para uma compreensão das múltiplas instâncias de discricionariedade na conformação do mandato policial e suas implicações para a accountability de polícia, ver: Muniz e Proença Jr. (2007b).
}

mam a PM ou se optam por resolverem os problemas por meios próprios, sejam eles violentos, excludentes ou discriminatórios. O segundo corresponde ao poder dos "agentes da lei e da ordem" de decidirem sobre a ação policial mais adequada a uma determinada chamada, ou mesmo de escolherem agir ou não agir diante de um evento ou em sua antecipação.

A produção de soluções policiais, quaisquer que sejam elas, combina essas instâncias discricionais, que não são necessariamente harmônicas e revelam, no plano do vivido, tensões cognitivas e práticas na condução dos eventos. Em cada decisão policial, tem-se um tipo de conciliação prática, desafiadora do que seja o legal, o legítimo, o politicamente autorizado, o ético, o tecnicamente válido e o socialmente tolerado. Tudo isso se manifesta em cada ocorrência, a cada contexto, no tempo presente dos acontecimentos, na urgência daqueles que se veem, por algum motivo, expostos aos riscos e perigos, reais ou imaginados, da vida em sociedade.

Por sua própria natureza e contexto, a ação policial só tem como ser produzida por uma abordagem autônoma. A solução policial, conformada pela discricionariedade dos cidadãos, encontra-se também premida pelas circunstâncias do momento, pelos imponderáveis da vida social. Ela responde às demandas inadiáveis, aos atos que estão em curso e têm de ser enfrentados no "agora". O que faz da polícia uma polícia é essa capacidade discricionária ${ }^{15}$ de construir, com o recurso potencial ou concreto à força, o enforcement consentido pelos cidadãos policiados e com sentido para eles mesmos e para os policiais.

Ao assumirem as ocorrências criminais de menor potencial ofensivo e não-criminais, definidas como prioritárias pela decisão discricionária dos paraibanos, os PMs de João Pessoa tam-

${ }^{15}$ Um entendimento instrumental da discricionariedade, amplamente aceito no direito administrativo brasileiro, é o proposto por Meirelles (2009, p. 39): a discricionariedade constitui-se num dos atributos do poder de polícia, que, para ser legítimo, deve ser exercido dentro dos limites legais, pois esse atributo “... não se confunde com arbitrariedade”. 
bém põem em operação o seu poder de polícia,, ${ }^{16}$ ou melhor, a sua decisão discricionária quanto aos meios e modos de cumprir o seu fim de ser, e seguir sendo, o senão da sociedade (Bittner, [1974] 1990 ).

O seu repertório de alternativas de obediências autorizadas para o agir faz parte de um precioso relicário de saberes-em-ato, muito apreciado exatamente porque resulta de um empirismo ou de um aprender fazendo nas ruas. Esse conhecimento prático, em estado de alerta para o imediato, é caracterizado, em seus próprios termos, como o modus operandis policial, do qual se extraem os famosos POPs - procedimentos operacionais padrão. Eles, em boa medida, são validados pela organização policial, servindo, por vezes, como uma orientação geral de comando, um "guia rex" para o decisionismo policial. Sua ambição instrumental é a de que sejam um receituário razoavelmente adaptável às idiossincrasias de cada situação e ao seu contexto.

Em nossa escuta junto aos praças de João Pessoa, foram identificadas seis categorias de POPs que, do ponto de vista deles, resumem os principais procedimentos que adotam tanto nas ocorrências criminais quanto nas não-criminais. São eles:

- Usar da força necessária para conter e controlar a situação.

- Resolver no local, harmonizando ou conciliando as partes.

- Chamar a atenção, advertir e (ou) repreender as partes.

${ }^{16}$ No Brasil, o poder de polícia é definido juridicamente no Código Tributário Nacional, Art. 78 da Lei 5.172/1966, elaborada no regime militar, e que dispõe sobre o "Sistema Tributário Nacional e institui normas gerais de direito tributário": "Art. 78. Considera-se poder de polícia atividade da administração pública que, limitando ou disciplinando direito, interesse ou liberdade, regula a prática de ato ou abstenção de fato, em razão de interesse público concernente à segurança, à higiene, à ordem, aos costumes, à disciplina da produção e do mercado, ao exercício de atividades econômicas dependentes de concessão ou autorização do Poder Público, à tranquilidade pública ou ao respeito à propriedade e aos direitos individuais ou coletivos. (Redação dada pelo Ato Complementar $n^{\circ} 31$, de 28.12.1966). Parágrafo único. Considera-se regular o exercício do poder de polícia quando desempenhado pelo órgão competente nos limites da lei aplicável, com observância do processo legal e, tratando-se de atividade que a lei tenha como discricionária, sem abuso ou desvio de poder" (Brasil, 2010a).
- Conduzir a(s) parte(s) à delegacia para desdobramentos legais.

- Conduzir para outro órgão competente.

- Explicar às partes que não se trata de assunto da polícia e orientar a procurar os órgãos competentes para solução do problema.

Todos esses encaminhamentos "táticooperacionais" fazem parte dos contornos do mandato policial em sua expressão concreta. ${ }^{17}$ Eles circunscrevem o como se pode, ou se deve, exercer os poderes delegados de polícia, indicando as exigências e predileções dos cidadãos policiados, dos governantes e dos agentes da lei sobre as alternativas que são desejáveis ou toleráveis na ação policial, para uma dada polícia, em uma dada sociedade, com um determinado governo. Estabelecem os limites contextuais da decisão policial, identificando o que estaria aquém ou além do enforcement consentido. São eles que qualificam os modos e os meios do agir e do fazer policial. Como uma grande moldura, eles delimitam o que pode estar dentro e o que pode estar fora da competência do PM, articulando, na prática, o que se espera que a polícia faça e o que a polícia faz, diante do que a polícia é.

Em um processo continuado de aproximações com o real da coisa, um ir e vir entre as leis do mundo e o mundo das leis, os POPs retratam uma espécie de concertação simbólica instrumental, ou, no jargão policial, um tipo de "termo (prático) de ajustamento de conduta" entre as expectativas sociais de justiça, as ambições de legalidade e legitimidade postas na ordem do dia. São, pois, uma bricolagem das prioridades políticas, das referências legais e normativas, das diretrizes organizacionais ou administrativas, das doutrinas ou métodos de ação, das demandas locais ou comunais, dos clamores, das vivências e das visões de mundo nascidas das experiências e experimentos entre os cidadãos e os seus policiais, diante das circunstâncias da vida real.

17 Uma apresentação analítica dos termos do mandato policial - âmbito, alcance e contornos - e seus fundamentos e aplicações pode ser encontrado em Muniz e Proença Jr. (2007b). 
Do conjunto de POPs considerados principais e que parecem atender ao grosso da rotina policial ostensiva, identificam-se aqueles considerados pelos PMs como "os que a gente mais usa" na resolução das ocorrências, segundo o seu potencial ofensivo, ilustrados no quadro abaixo:

Quadro-resumo dos procedimentos mais usuais na resolução das ocorrências policiais, de acordo com o potencial ofensivo

\begin{tabular}{|l|l|}
\hline Natureza da ocorrência & \multicolumn{1}{|c|}{ Procedimento mais usual } \\
\hline $\begin{array}{l}\text { Criminais de maior } \\
\text { potencial ofensivo }\end{array}$ & $\begin{array}{l}\text { Conduzir para a delegacia de polícia. } \\
\text { Usar da força necessária para conter } \\
\text { ou controlar a situação. }\end{array}$ \\
\hline $\begin{array}{l}\text { Criminais de menor } \\
\text { potencial ofensivo }\end{array}$ & $\begin{array}{l}\text { Conduzir para a delegacia de polícia. } \\
\text { Resolver no local, conciliando, } \\
\text { repreendendo ou usando da força } \\
\text { para conter. } \\
\text { Orientar a procurar outro(s) órgão(s). }\end{array}$ \\
\hline Não-criminais & $\begin{array}{l}\text { Conduzir para a delegacia de polícia. } \\
\text { Resolver no local, conciliando, } \\
\text { repreendendo ou usando da força } \\
\text { para conter. } \\
\text { Orientar a procurar outro(s) órgão(s). } \\
\text { Encaminhar para o órgão competente }\end{array}$ \\
\hline
\end{tabular}

Fonte: Silva (2009)

Com o auxílio dos materiais etnográficos construídos no decorrer da pesquisa, podem-se extrair desse enquadramento geral alguns pontos importantes para a compreensão da gramaticalidade decisória policial.

Oprimeiro deles, de natureza epistemológica, diz respeito ao processo mesmo de externalizar, de pôr na ordem do discurso, aquilo que se faz. A enunciação em palavras do que se faz e do que se pensa sobre o que se faz resulta de um jogo próprio do significar, que pressupõe instâncias de negociação - cumplicidade, confiança, reconhecimento e aceitação - entre os atores no contexto interativo. Um jogo lúdico "de gato e rato", que envolve a produção de sentidos consentidos e nãoautorizados entre os interlocutores, cuja engrenagem, mais ou menos intencional, admite estratégias seletivas e pactuadas de ocultações e revelações. O verbo que se faz carne verbalizada, entre os PMs e os outros, é desvendado porque também habita em nós, em nosso senso comum e ilustrado. $\mathrm{Ou}$, como prefere a antropologia, também habita em nosso imaginário social acerca da polícia e de suas práticas de policiamento. Esse verbo, em texto e em seu contexto, traz a sua graça e verdade, porque seus enunciados, como qualquer enunciação, publicam mesmo que sem publicizar, deixando entrever, nas entrelinhas, o que está ou o que se quer como subentendido ou conscientemente externado.

O segundo ponto dirige-se à teoria nativa do mandato policial, que se pode apreender dos procedimentos de atuação que foram priorizados pelos PMs, segundo a natureza da ocorrência. O saber prático dos PMs paraibanos, ao seu modo e tão ao gosto da teoria de Bittner ([1974] 1990), insinua uma hierarquia funcional entre os POPs cujo fio condutor é a distribuição gradativa, reversa e redundante dos níveis de coercitividade para conduzir os eventos, de acordo com o que seja o seu potencial ofensivo. Em termos instrumentais, os PMs estabelecem um escalonamento no uso do núcleo central de seus poderes discricionais, retratado nos chamados gradientes de uso da força - potencial e concreta - para a resolução das ocorrências. Tal escalonamento vai do "não tem conversa, 'teje' preso" até "liberação" ou "encaminhamento das partes", passando por sua conciliação, repreensão ou aconselhamento. Ou, num caminho inverso, vai do "ainda dá para conversar", passando pelo "chamar à consciência" ou "passar uma reprimenda", até o "agora, você vai ter que se ver é com a justiça". Ou, também, há o acionamento pelo policial de várias dessas alternativas, em uma mesma ocorrência, para conseguir encerrar o caso. ${ }^{18}$ Essas alternativas de força aparecem para os PMs como táticas conti-

${ }^{18}$ Um rumo de compreensão da discricionariedade sobre o que chamamos de distribuição gradativa, reversa e redundante de coercitividades pode ser encontrado em Kenneth (1969), em seu livro intitulado Discretionary Justice. O autor chama atenção para duas possibilidades lógicas da decisão discricionária: o "agir" ou "não agir" numa determinada situação. Já Klockars (1985) e Muniz e Proença Jr (2007b) esclarecem que, na práxis policial discricionária, o "não agir" aparece como uma alternativa decisória possível, válida e, por vezes, superior, aberta ao policial para produzir a solução mais apropriada e oportuna para a circunstância enfrentada. Isso permite circunscrever a totalidade do "decisionismo policial" em termos de sua publicidade, visibilidade e oportunidade de controle e accountability. 
nuadas, igualmente válidas, servindo, conforme as circunstâncias, como um repertório de senões para o antes, o durante e o depois dos eventos, colocados à disposição dos cidadãos. Como, por exemplo, a decisão de encaminhar para outros órgãos, seja porque o problema visto de perto revela-se como não sendo um problema de polícia, seja porque a competência da PM na sua condução foi encerrada.

Note-se que, em todos esses procedimentos policiais identificados como operacionais, porque dariam certo, como padrão, porque poderiam servir de guia, e como mais usados, porque funcionariam e orientariam a ação policial, revela-se um atributo importante da produção de obediências consentidas. Trata-se da assimetria de poder entre quem detém a prerrogativa do uso legal e legítimo de força e aqueles sobre os quais esse recurso está autorizado a ser empregado.

Esta assimetria, posta de antemão, entre policiais e cidadãos, condição de possibilidade para o exercício do poder de polícia, com ou sem consenso, demarca a fronteira entre uma segurança pública para todos e os mecanismos tradicionais de proteção para poucos. É essa assimetria que distingue a polícia pública de um bando armado a mais, possibilitando a construção de algum enforcement. Isso quer dizer que todas as soluções policiais, declaradas ou justificadas como preventivas, dissuasórias ou repressivas, trazem uma medida de coercitividade, o que as torna possíveis e as faz demandadas pela população. Chama-se a polícia para tudo. Chama-se a polícia quando (só) pedir não basta.

Assim, as orientações extraídas dos POPs dos PMs de João Pessoa servem como um case que evidencia que a sinfonia policial - em seus atos de conciliação, de aconselhamento, de correção moral, de advertência, de levar para a delegacia etc. - é constituída de variações sobre o mesmo tema (controle e regulação social) e que os regentes policiais concertam, fazendo uso de uma variedade graduada de instrumentos potenciais ou concretos de força para o público e sob a apreciação deste mesmo público. A rigor, a diferença entre os POPs não é de natureza e sim de grau. Talvez por isso, os PMs paraibanos, de posse de sua sociologia nativa, estão sempre prontos a dizer que "o que eu sou mesmo é polícia”. E porque eles são uma autoridade policial, com ênfase no policial, possuem as tais competências residuais, fazendo os papéis de pai controlador, de psicólogo, assistente social, de parteiro, de despachante, de Florence Nightingale in Pursuit of Willie Sutton (Bittner, [1974]) 1990), enfim, de "agentes itinerantes de justiça local de primeira hora".

Tudo isso, é claro, encontra guarida e ânimo nas expectativas populares de um tipo de justiça que, para ser justa, não pode estar perto demais, nem longe demais. Tem que estar entre as pessoas e junto aos fatos, estabelecendo uma boa medida entre o que se ambiciona como universal - está valendo para todos - e o que se quer como particular - "o meu caso é diferente dos outros". E se espera que esse "espírito da lei" esteja incorporado no policial, como antecipou Skolnick (1966), em seu livro Justice Without Trial: Law Enforcement in Democratic Society. Esperase, pois, que esse seja o papel da polícia, como relata um representante do Ministério Público paraibano: “... o policial militar é quem está em contato direto com o povo; é quem sabe das coisas. Ele é quem faz a verdadeira justiça, pois a justiça, para que ela seja importante, tem que ser feita na hora".

Espera-se, portanto, que seja esse o seu verdadeiro enforcement, traduzido em POPs, o que, afinal, esclarecendo a razão de ser das polícias em sociedades democráticas, permite compreender as implicações que isso possa vir a ter em uma sociedade de democracia emergente, como a brasileira. Trata-se de uma realidade na qual experimentamos uma desigualdade jurídica naturalizada (Lima, p.1999), teatralizada por uma cidadania relacional (Da Matta, p.1979), que se vê e se faz "regular" por uma administração estatal do poder delegado de polícia, cujo mandato público apresenta-se como uma procuração em aberto ou como um "cheque em branco" (Muniz; Proença, 2007b). 
O estado dos procedimentos que saem da boca dos PMs revela a existência de, ao menos, dois requisitos funcionais que concorrem para a construção de um encaminhamento policial aceitável: (i) a percepção do grau de risco e de lesividade dos eventos criminais ou não-criminais; e (ii) a possibilidade, sempre aberta, de resistência dos envolvidos, até mesmo de sua recalcitrância armada, à presença, à expectativa de presença e à solução dos policiais. O primeiro requisito fala mais diretamente da fabricação de legalidades e suas implicações formais para os cidadãos e para os próprios policiais. O segundo fala mais diretamente da fabricação de legitimidades, ou do reconhecimento e da aceitação da autoridade policial pelos policiados. Um e outro se subordinam ao pragmatismo do "decisionismo" do policial, que sabe como funciona o sistema entre nós. E, por isso, ele está sempre atento à "repercussão na sociedade" e frente ao governador e sempre alerta para os comprometimentos legais e institucionais acerca de suas decisões e os custos delas para a sobrevivência na carreira policial. Aqui, a decisão discricionária segue levando em consideração os conteúdos práticos dos contornos de seu mandato. À moda brasileira, isso significa dizer que os PMs paraibanos, “calejados toda vida”, traduzem as exigências da polity - sociedade e seu governo - olhando para quem pode estar no alto, em baixo, ao lado e ao redor, tentando caminhar entre as discricionariedades - em muitos casos, arbitrariedades - ora convergentes, ora divergentes, dos seus diversos "patrões", como é ilustrado por Muniz e Proença Jr. (2007c) no artigo Muita politicagem, pouca política os problemas da polícia são.

Para tentar "fazer a coisa certa", decidir pelo POP mais apropriado, é preciso, então, usar do bom senso policial e considerar o que manda a lei, avaliando, em cada situação concreta, a possibilidade de justificativa e de desdobramento legais. Trata-se de sopesar, por exemplo, se a ocorrência criminal ou não-criminal pode ter uma tipificação delitiva rentável, alguma materialidade que sirva para alimentar a linha de produção do sistema criminal que processualiza corpos, vontades e coisas. Para encaminhar para a delegacia, é prudente ponderar se o fato típico vai dar em algo mais à frente, ou se é melhor resolver no local, porque se sabe que "não vai dar em nada". Ou seja, se a ocorrência será "quebrada" mais adiante, servindo apenas para desmoralizar o PM - entenda-se também deslegitimar, "prender a (sua) viatura na porta do distrito policial”, e gastar o seu tempo, ainda mais com os trâmites cartoriais para o registro da ocorrência.

O realismo pragmático dos PMs recomenda que, diante do risco sempre iminente de ser acusado de prevaricação ${ }^{19}$ por alguém insatisfeito com trabalho da polícia, é de fundamental importância que se construa, sempre que possível, uma camada de legalidade: por exemplo, passando o bastão adiante para o delegado, quando se está diante de um ato potencialmente criminal e, em alguma medida, ofensivo.

Mas, para sustentar alguma legalidade para a decisão policial, é preciso também negociar, no ato das ocorrências, alguma instância de legitimidade. E isso significa afirmar, (re)construir e até mesmo resgatar o assentimento público, ali representado pelas partes, em situações que expressam ordens distintas de resistência ao exercício da autoridade policial. Faz-se necessário repactuar o consentimento social ao mandato de polícia, rememorando e afirmando, pela decisão policial em contexto, a anterioridade política, social e legal de seus termos. Para policiar, a polícia precisa dispor de - e, ao mesmo tempo, constituir - algum nível de reconhecimento e autorização. Isso se traduz na sua capacidade de dobrar a(s) resistência(s) que emergem em cenários entrecruzados de intencionalidades e acidentalidades de toda sorte, virtualmente conflituosas e quase sempre temperadas por expressões afetivas desmesuradas.

${ }^{19}$ O Código Penal Brasileiro, Decreto-lei no 2.848, de 7 de dezembro de 1940, define o crime de "prevaricação" em seu artigo 319, aqui reproduzido: "Retardar ou deixar de praticar, indevidamente, ato de ofício, ou praticá-lo contra disposição expressa de lei, para satisfazer interesse ou sentimento pessoal: Pena - detenção, de três meses a um ano, e multa". 
Isso significa estar preparado para o enfrentamento dos problemas, lançando mão de POPs para esfriar ou apaziguar os ânimos exaltados dos chamados "bandidos" e, sobretudo, dos "cidadãos de bem", que, tendo direitos - para muitos, "privilégios"-, acham que estão sempre com a razão, podendo "crescer para cima" de uma das partes e (ou) da autoridade policial.

Quando a polícia chega, muitos se alimentam da presença da polícia pra começar a disputa. Fazem da polícia um escudo, aí quer ter direito de xingar. Á já cria uma outra situação. Muitas das vezes, o pessoal, quando vê a viatura, aí quer "crescer", principalmente mulher, dizendo: "Dê em mim agora, dê agora pra você ver!”. Ela se sente fortalecida porque foi ela que solicitou. (Cabo, com 16 anos de serviço)

Na linguagem dos POPs, a resistência ${ }^{20}$ entre as partes e, sobretudo, delas em relação ao policial, é caracterizada como passiva ou ativa, conforme a percepção da periculosidade dos envolvidos. Idealiza-se um continuum de aceitações coercitivas, que vai de uma atitude mais cooperativa até a menos cooperativa, inclusive armada, para com a condução policial. É diante dessa expectativa de cooperação, ou melhor, de níveis negociados de adesão à autoridade de polícia, que se estabelecem as alternativas potenciais e concretas de força. Instrumentaliza-se, nos termos "tático-operacionais", um fluxo desejado de correspondências entre condutas, nas quais a conduta das partes iria da submissa até a agressiva letal, e a do policial razoável, em prontaresposta à primeira, caminharia do comando verbal até a força mortífera. É, portanto, com essa ambição de conformidade que se racionaliza e se busca justificar a proporcionalidade do decidir e do agir policiais, assentada na chamada "doutrina do uso progressivo de força,"21 gestada

${ }^{20}$ O Código Penal Brasileiro define o tipo criminal resistência, em seu artigo 329, da seguinte forma jurídica: "oporse à execução de ato legal, mediante violência ou ameaça a funcionário competente para executá-lo ou a quem lhe esteja prestando auxílio" A pena prevista é a de "detenção, de dois meses a dois anos" (Brasil, 2007).

${ }^{21}$ No Brasil, até então, inexiste, na legislação doméstica, um protocolo para o uso da força pelos agentes com poder de polícia que referencie os termos normativos, políticos e técnicos, contornos do mandato policial. Por conta disso, temos como documento de orientação a legislação interna- nos meios policiais e que, mais recentemente, foi adotada como uma recomendação pela Secretaria Nacional de Segurança Pública (SENASP), do Ministério da Justiça. ${ }^{22}$

O emprego amplamente disseminado da noção de proporcionalidade pelos PMs, que corresponderia conceitualmente à de suficiência, que articula os juízos de propriedade e oportunidade da ação policial (Muniz; Proença Jr., 2007a), tem a sua razão político-pedagógica de ser. Ela aparece como um dispositivo para a produção de legitimidades, perante as resistências, que estabeleçam uma sintonia com o senso comum e, especialmente, com o senso comum jurídico e político, que avalia o mérito da ação policial. Os policiais, em geral, e os PMs da Paraíba, em particular, sabem, por força da prática, que o comedimento desejado no uso dos recursos coercitivos não tem como ser traduzido automaticamente em proporcionalidades do tipo resposta-comando-resposta. Isso porque se pode ter de decidir agir de menos, agir de mais e, principalmente, não agir, para poder produzir soluções superiores, igualmente válidas e capazes de responder, de forma apropriada e oportuna, porém desproporcional, às circunstâncias, aos termos do mandato policial, às prioridades da política pública. Sob essa perspectiva, as alegações morais e técnicas de proporcionalidade frente às resistências revelam-se tão somente como estratégias de legitimação para respaldar o exercício da autoridade policial.

Isso fica bastante evidente nas escolhas dos PMs quanto aos POPs mais empregados nas ocorrências criminais de menor potencial ofensivo e nas não-criminais, que envolvem questões

cional, especificamente o Código de Conduta para os Encarregados da Aplicação da Lei (CCEAL) e os Princípios Básicos sobre o Uso da Força e Armas de Fogo, ambos instituídos pela ONU. O art. $3^{\circ}$ do CCEAL, em particular, instituído pela Resolução da ONU n ${ }^{\circ} 34 / 169$, de 17 de dezembro de 1979, define que "os funcionários responsáveis pela aplicação da lei só podem empregar a força quando estritamente necessária e na medida exigida para o cumprimento do seu dever." (Rover, 1998, p.464).

${ }^{22}$ O Caderno Temático 5 da 1a Conferência Nacional de Segurança Pública, a CONSEG, realizada no final de 2009 e promovida pela SENASP/MJ, dedica-se ao "Uso Progressivo da Força: Dilemas e Desafios”, e pode ser encontrado no portal: www.conseg.gov.br. 
sem maior gravidade para a justiça criminal e que dizem respeito ao universo heterodoxo dos conflitos interpessoais, ao complexo "feijão com arroz" da ordem pública.

De uma maneira geral, essas ocorrências não são pensadas como pertencentes à criminalidade, constituída por malfeitores que "não têm o que perder". Ao contrário, elas teriam como protagonistas cidadãos que passam por dificuldades, têm problemas e chamam a polícia. Pessoas que podem ter dado um "mau passo na vida", mas que são, em sua maioria, "humanos direitos" para os quais os direitos humanos aparentemente fariam mais sentido.

Agressão física sem ferimento ou lesão, xingamento, insulto ou ofensa moral, ameaças, dívidas, mendicância, atrito verbal, discussão ou bateboca, perturbação do sossego, briga entre vizinhos, conflito amoroso, jogar lixo na rua, arruaça, bebedeira, transtorno mental, obscenidade, fazer cocô exixi na rua, pichação, menor abandonado ou cheirando cola, pessoa desaparecida, etc., fazem parte do rol de problemas para os quais a cidadania mobiliza os PMs de João Pessoa. E é aí, quando se tem alguma cidadania envolvida, que se pode melhor compreender porque as soluções policiais têm muito depende para se constituírem como um senão social. Depende de quem é o cidadão, de sua disposição cooperativa, da sua aceitação da polícia, do tipo de conflito em que está envolvido, dos meios policiais de que se dispõe para escolher os modos de ação e depende, também, da suscetibilidade do policial na confrontação do seu dever com o direito de todos. Pois cada um, no exercício desmedido de sua própria razão, a razão de classe, por exemplo, pode querer tirar alguma vantagem do PM, ou demandar uma solução que atenda à sua demanda particular pela intervenção de uma autoridade.
No caso de briga entre moradores de classe média, a expectativa deles é de que não vai mais ocorrer o problema pela presença da polícia naquele momento e o constrangimento. Assim, no meu entender, eles chamam a polícia pra que, no caso, o acusado, se sinta pressionado a não fazer mais, no caso, não ligar o som alto, não fazer uma baderna na garagem. (Sargento, com 7 anos de serviço).

As pessoas da periferia, quando chamam a polícia, chamam com o propósito de intimidar. Quando a polícia chega, eles dizem: 'Tira onda agora, misera! Vai desgraça, tira onda agora, tu né brabo!' É desse jeito. (Cabo, com 17 anos de serviço).

Equilibrando-se na corda bamba da legalidade e da legitimidade, no dilema prático entre o "agi mais do que devia e podia" e o "agi menos do que devia e podia", os PMs optam, pragmaticamente, por não complicar o que já é complicado por sua própria natureza. Afinal, os pequenos delitos e eventos não-criminais abrem-se a irracionalidades, a uma maior imprevisibilidade, exatamente porque envolvem querelas pessoais teatralizadas por meio de chantagens, vinganças, descontrole emocional, meias-verdades e "picuinhas" de todo tipo. E, por isso, são aqueles que, do ponto de vista dos policiais, mais podem "complicar o lado do PM", como ilustrado no Gráfico 3.

Aos olhos dos policiais, os cidadãos querelantes, marinheiros de primeira viagem na condução de seus conflitos, não possuiriam um modus operandi, reações previsíveis como a "bandidagem", deixando-se mais facilmente contagiar por atitudes destemperadas e inconsequentes em nome da

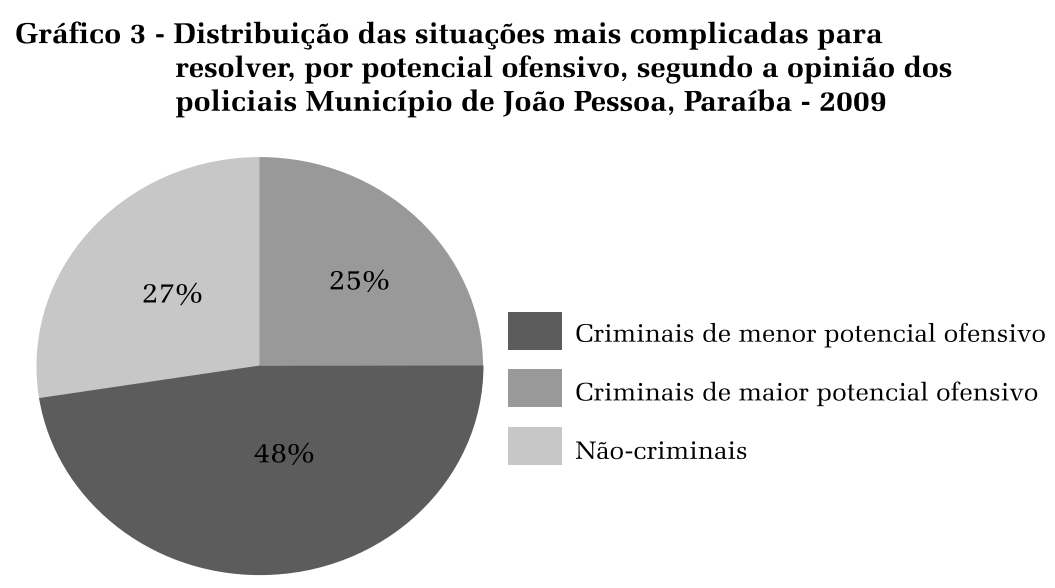
Fonte: Silva, W. (2009) 
defesa de suas próprias razões. Como "caldo de galinha” e muita paciência não fazem mal a ninguém, as soluções de resolver no local; encaminhar para outro órgão; ou dar condição para as partes se explicarem e entrarem num entendimento, apresentam-se como alternativas razoáveis, mesmo quando se espera encontrar resistências. Pode-se, com isso, encerrar ali mesmo o problema, sobretudo liberando os PMs para seguirem ao encontro de outra ocorrência.

Um atrito verbal, uma vias de fato, que a gente vê que os ânimos estão calmos, que não tem potencial ofensivo pra guarnição, nem pras pessoas envolvidas que estão no local, a gente tenta orientar que cada um vá pras suas casas, se nenhuma das partes quiser prestar queixa. (Cabo, com 23 anos de serviço)

A gente chama as duas partes, primeiro, separa as duas partes e tenta entender o motivo que ocasionou as vias de fato, a versão de cada uma das partes. Baseado nisso aí, a gente vai tomar uma posição. Se uma das partes, realmente, teve o envolvimento no início das vias de fato, a gente, dependendo da posição da outra parte, leva pra delegacia. Senão, se ela disser: "Nã̃o, eu só quero ir pra minha casa mesmo, evitar problema e tal. Foi ele que procurou confusão comigo, eu não queria nenhuma confusão, só fui revidar a agressão", então, se nenhuma das partes quer ir pra delegacia, a gente resolve no local. Agora, se nenhuma das partes chega a um entendimento e a gente também não sabe quem começou a agressão, a gente leva pra delegacia pra ser apurado. $\mathrm{O}$ delegado coloca tudo num termo circunstanciado e é apurado. (Cabo, com 23 anos de serviço).

Assim, os POPs mobilizados pelos policiais para dar conta daquilo que pode vir a se tornar perigoso e violento, sejam os pequenos delitos, sejam as desordens, incivilidades e conflitos, evidenciam a motivação inicial, realista, de construir soluções que não evoluam rumo à burocracia legal. Eles escolhem, primeiramente, não criminalizar essas ocorrências, alternando encaminhamentos não-legais ou alegais para sustentar a expectativa de legalidade com a legitimidade carimbada pelas partes envolvidas. Eles buscam, assim, empreender uma adesão compelida ao “espírito da lei” e negociar um sentido de justiça, decidindo por não fazer nada em termos da aplicação estrita da legislação.

Mas, como tudo no trabalho policial tem um depende, para produzir enforcement nesses eventos, principalmente os não-criminais, considera-se o uso concreto de força para reverter as resistências. Tal evidência surpreende as expectativas convencionais de que onde não haveria um fato propriamente criminal, a "ação enérgica do policial” ou o "emprego da força necessária” para conter os ânimos exaltados dos cidadãos seriam remotos. Note-se que os PMs entrevistados verbalizaram explicitamente essa opção do recurso à força como uma das que mais utilizam. E eles têm boas razões para isso.

Quanto mais os atos se distanciam da possibilidade de serem convertidos em fatos delitivos típicos, mais eles enunciam suas idiossincrasias, mais eles anunciam seus componentes de refração ou irredutibilidade a racionalizações, e mais eles sinalizam para oportunidades de ruptura ou insurreição classificatória, evidenciando sua complexidade e sua multiplicidade de sentidos por negociar. Mesmo lá, no paraíso das ocorrências não-criminais inomináveis da ordem pública, para as quais não se tem uma expressão formal em lei, tem-se a força legítima da espada para sustentar a desejada paz social, intervindo na imprevisibilidade, nas resistências por ela alimentadas. ${ }^{23}$ Tem-se a busca de afirmação da autoridade policial e de seu consentimento para conduzir a uma solução que seja razoável.

Não é incomum que as ocorrências nãocriminais apresentem um potencial ofensivo que poderia redundar em violações e violências com riscos de vitimização tanto civil quanto policial. Por sua vez, não é incomum que essas situações, pela sua natureza, apresentem atitudes recalcitrantes ou não-cooperativas. Inúmeros são os eventos relatados pelos policiais nos quais se mobiliza a polícia ao mesmo tempo em que se manifesta a recusa de sua intermediação: um tipo de reação corriqueira que, por diversas motiva-

\footnotetext{
${ }^{23}$ Chama atenção a "interlegalidade" das ocorrências nãocriminais, cujos eventos que cobrem admitem o acionamento de outros direitos. Onde direito penal silencia, o direito civil e, sobretudo, o direito constitucional costumam ser acionados pelo senso comum policial para sustentar uma legalidade tanto no processamento da ocorrência dentro do que seria entendido como o escopo da "competência policial", quanto no seu encaminhamento a outros órgãos.
} 
ções, como o medo de represália, o vinculo pessoal com o oponente, a desconfiança da polícia, etc., veicula a mensagem contraditória de "não meter o bedelho onde se é chamado".

Identificadas pelos policiais como "as mais complicadas de resolver", tais ocorrências, que desfrutam de baixa visibilidade social e, em boa medida, passam ao largo da justiça, são aquelas atravessadas por incertezas irrestritas. Particularmente, nessas manifestações entre cidadãos comuns, é que "tudo pode acontecer". Suas expressões conflituosas, desordeiras e incivilizadas propiciam a ocorrência de desacatos e abusos de autoridade.

Além de ser chamado de "seu guarda", nada desagrada mais o policial do que ter a "moral" de PM atingida e ver questionada ou destituída a sua autoridade para conduzir a ocorrência. E isso é ainda mais frequente nas tais ocorrências não-criminais do que imagina a nossa sensata consciência.

Em alguns casos, a indiferença à autoridade policial acontece porque os envolvidos experimentam estados alterados de consciência que os impedem de compreender e seguir a orientação policial. Pessoas embriagadas, drogadas, com transtornos emocionais ou psíquicos, frequentemente oferecem níveis significativos de resistência passiva e ativa, expondo a si mesmas e aos outros a riscos de vitimização. Quem já teve a oportunidade de acompanhar o esforço policial de "colocar um bêbado na viatura" ou de "resgatar um alienado mental" pode também observar o quão complexo é o uso concreto de força para produzir imobilização defensiva em pessoas alheias a quem lhes faz a guarda. Trata-se de situações em que se costuma usar de um quantum maior de força do que a expectativa de ameaça oferecida. ${ }^{24}$ Aqui, o PM tende a escolher agir demais, para fazer o razoável.

${ }^{24}$ Na coletânea Aspects of Police Work, Bittner (1990) reflete sobre as práticas policiais de peacekeeping e de apprehension of mentally ill persons, como ilustrações da produção de enforcement pela polícia e, por sua vez, da complexidade do seu mandato de produção de obediências sob consentimento.
Em outros casos, até mais frequentes do que os anteriores, a recusa da autoridade policial é intencional, podendo se manifestar desde o início. Neles, os cidadãos em conflito, "esquentando a chapa", produzem deliberadamente resistência passiva ou ativa para obter um resultado que atenda mais imediatamente a seus interesses, por sobre ou com a chancela policial. Quem já teve a oportunidade de acompanhar o esforço policial para mediar um conflito doméstico ou de fazer cessar o bate-boca entre conhecidos também pode observar o quão complexo é usar do concreto de força para pacificar os ânimos ou produzir submissão e retomar o controle daqueles que intencionalmente manipulam o policial como a terceira parte. Trata-se de situações em que se costuma usar de um quantum menor de força do que a expectativa de ameaça oferecida. Nelas, o PM tende a decidir agir de menos para fazer o razoável.

Nessas situações, por distintos fatores, ocorrem expressões de desobediência, com ou sem sentido, às regras pactuadas do jogo da ordem pública e, por sua vez, aos termos do seu enforcement, representado na figura do policial e de sua autoridade. Ressalte-se que as resistências provocadas entre as partes e delas em relação ao agente da lei assumem um caráter de desobediência provocativa ao policial, a qual favorece uma percepção ampliada do potencial ofensivo nas interações entre cidadãos e policiais. Como uma importante pista, elas sinalizam não apenas desentendimentos pontuais entre cidadãos policiados e sua polícia, que poderiam não estar falando a mesma língua. Elas remetem ainda a algo mais estrutural do exercício dos mandatos de policiamento publico e estatal entre nós, pois dizem respeito a dinâmicas latentes ou explícitas de desautorizações consentidas, que produzem deslegitimações continuadas da autoridade policial. E, com isso, sabotam a condição democrática primeira para se policiar: a autorização pública, coletiva, para produzir obediências ao pacto social sob o império da lei. Elas indicam a perspectiva sempre aberta de subalternização do lu- 
gar e do sentido mesmo de uma autoridade pública orientada pelos princípios universais da igualdade e da imparcialidade, os quais poderiam colocá-la como uma terceira parte, autônoma e independente, entre nós e os outros. Assim, tais resistências esclarecem que fazer polícia "à moda brasileira" pode significar navegar entre "carteiradas" que viriam de todos os lados: mais uma vez, do alto, de cima, de lado e ao redor do decidir policial.

\section{“ELES ESTÃO DESCONTROLADOS?” AUTO- RIDADE DE MAIS, AUTORIDADE DE MENOS NA GESTÃO DAS OCORRÊNCIAS}

"Mulher pelada, cachorro doido e PM (não) podem tudo", como, à primeira vista, somos levados a fabular. Na prática, a fantasia de "superpoderes" democráticos da autoridade policial para sustentar o status quo estabelecido pela polity, para garantir uma ordem de todos para todos, é bem outra entre nós. O PM pode bem menos do que são, ou deveriam ser, os poderes delegados por seu mandato público. E sempre pode bem mais quando se encontra "de serviço" e acontece de ter de se colocar a serviço de algum patrão da vez. Pode mais quando é forçado a atender a algum pedido particular. Pode tudo, ou quase tudo, quando é constrangido a pagar um favor pessoal, a "fazer vista grossa", a dobrar-se a uma camaradagem pedida "com jeitinho" pelos diversos "quem", que se veem e se reconhecem como pessoas (Da Matta,1979): cidadãos de primeira classe que estariam por sobre e ao largo da lei. Na lida cotidiana da administração pública da segurança, temperada por nossas práticas clientelistas, a ocasião não faz só o ladrão. Faz aparecer também os patrões de ocasião e sua lista sempre aberta de protegidos. Tudo isso conforme o acaso das ocorrências e o infeliz ocaso policial de colidir com quem tem "costas quentes", quem pode sacar uma "carteira de autoridade" mais poderosa que o distintivo da polícia.

Saídos do mundo popular, os praças da
Paraíba experimentam os dois lados da nossa moeda do poder, de uma sociabilidade política com o lastro brasileiro, que põe em circulação uma realidade ambicionada como igualitária, mas reencenada como desigual (Lima, 1999). Como policiais, eles partilham da condição de autoridade, com alguma medida de poder, com alguma medida de autorização pública. Como cidadãos emergentes da classe trabalhadora, eles partilham da situação de "ter de procurar os seus direitos". De ter também de precisar chamar por, e negociar com, uma autoridade que, de fato, possa mais, que possa vir ao encontro do PM para corrigir uma injustiça na ocorrência policial, compensando a sua falta de autoridade, por conta de seu alegado déficit de cidadania. Como fica "a cabeça" do PM que necessita colocar-se, todo o tempo, na fronteira mesma entre a convivência diária com oportunidades de apropriação privatista de seu mandato público e a possibilidade sempre aberta de acusação de conivência com quem manda mais?

Na área nobre, por mais que a guarnição esteja certa, a gente tá errado. Eles questionam e começam a intimidar a guarnição. A dificuldade aqui de serviço é só essa. Diante dessa situação, geralmente chamamos o oficial de serviço. Nos sentimos acuados para agir, pois temos medo de ser punidos. Às vezes, a gente age certo e vem por trás uma pancada, geralmente de superiores. (Cabo, com 17 anos de serviço) (grifos nossos)

O saber policial de rua recomenda que a "cabeça” do PM não se esqueça de ponderar a conveniência do uso de seus procedimentos operacionais padrão, mapeando, de partida, "com quem (se) está falando" e seus apetites por ilegalidades privilegiadas.

A questão da embriaguez é uma ocorrência delicada, porque, geralmente, são pessoas de situação financeira alta que, às vezes, ficam complicando pra gente dar andamento à ocorrência. Porque, geralmente, quando acontece uma situação desse tipo, sempre vêm aquelas perguntas: "Sabe quem eu sou? Sabe com quem tá falando? Sabe quem eu conheço?" Então, esses tipos de ocorrências são muito melindrosos. (Cabo, com 17 anos de serviço) (grifos nossos)

Com relação aos casos de maior dificuldade do policial administrar, o que eu percebo é que tudo vai depender do grau de escolaridade do queixante, do queixoso e do poder aquisitivo dele. 
Eu acho, inclusive, que a radiopatrulha se sente menos preparada quando se depara com uma pessoa abastada do que com o pobre. (Oficial, com 3 anos de serviço)

É preciso seguir fabricando legitimidade, mas "cobrindo o próprio lado", levando em consideração o consentimento da polity para policiar. Só que, em um contexto de imprecisão política das competências federativas, de baixa normatividade e de vagueza administrativoprocedimental quanto ao que sejam os termos do mandato de polícia no Brasil, que ainda persiste como uma procuração em aberto, mesmo após a redemocratização (Muniz; Proença Jr., 2007c). É, então, preciso seguir relevando o "tal" do consentimento que, no mundo de práticas cordiais e autoritárias, acontece transversalizado por razões de compadrio, de classe, de renda, de cor, de prestígio social, de posição hierárquica e de outras mais que possam vir a "fazer a diferença" em um fazer-se desigual na gestão das ocorrências.

Eu acredito que a pessoa com poder aquisitivo e com alto grau de escolaridade pode vir a prejudicar ou questionar o serviço do homem da RP [rádio-patrulha]. E quando a pessoa não tem dinheiro ou não tem instrução, ela não questiona ou questiona muito pouco. (Oficial, com 3 anos de serviço).

Já as pessoas de classe média gostam muito de dar pitaco, de tentar se defender e ir contra a polícia. Muitas vezes, não acham correto o trabalho da polícia. (Soldado, com 2 anos de serviço).

Na maioria das vezes, o policial se sente "pisando em ovos", já que, no lusco-fusco da nossa cidadania regulada, não fica muito claro quando é para exercer plenamente o lugar público de autoridade, quando se pode ser autoridade "de mais", quando se deve ser autoridade "de menos". O que se tem como perspectiva interativa entre cidadãos policiais e os outros cidadãos é uma realidade que se mostra potencialmente ofensiva a um "alguém". Uma realidade na qual a distribuição estatal de coercitividades legais e legítimas admite não apenas a presença ostensiva do PM, mas também a ação ostentatória de intermediários, atravessadores ou mercadores do poder público de polícia, que vai corroendo o direito (de- legado) do estado de afirmar o estado de direito dos seus cidadãos. E, entre esses despachantes consentidos a fazer uso da polícia para seus fins particulares ou de outros, encontra-se a própria clientela policial. Na dinâmica cotidiana de “carteiradas”, há desautorizações recíprocas e continuadas entre os próprios promotores da lei.

Quando foi perguntado aos PMs que fatores mais complicam as suas intervenções nas ocorrências, apurou-se que a maior parte das respostas (65\%) referia-se ao envolvimento de policiais, especialmente de superiores hierárquicos, outras autoridades e seus amigos ou afilhados, na condição de infratores. Tal como ilustrado de forma desagregada na Tabela 1, os quatro fatores mais relevantes são: envolvimento de amigos de superiores hierárquicos (16,7\%); envolvimento de outros policiais militares, sobretudo superiores hierárquicos (16,3\%); envolvimento de policiais civis e ou federais (16,2\%); e envolvimento de autoridades políticas e judiciárias (15,6\%).

Destaque-se que as referências dos PMs aos "suspeitos de sempre" de João Pessoa como fatores que tornam complexa a ocorrência - bêbados, drogados, perturbados mentais, indivíduos armados, menores infratores, lutador de artes marciais e pessoas com baixa escolaridade -, corresponderam a somente $22 \%$ do conjunto de respostas válidas. Ao considerar esse retrato fotografado pelos PMs que vêm "de baixo" e que estão abaixo na hierarquia policial-militar, evidencia-se quem dá mais trabalho para a polícia: os cidadãos que se apresentam como "acima de qualquer suspeita", dentre os quais, evidentemente, estão aqueles com maior poder aquisitivo ou escolaridade, que receberam $12,5 \%$ das respostas obtidas.

Foi-se o tempo do patrimonialismo à moda rural, no qual a polícia era só do senhor das terras, ou do senhor dos negócios, ou do interventor governamental. O que se pode aventar com os relatos dos PMs paraibanos é a de sua versão contemporânea, revista e ampliada, na qual se observa o uso do poder coercitivo como uma mercadoria política, que se abre à geração de receitas informais e ilegais (Misse, 2007; Muniz; Proença 
Tabela 1 - Fatores que mais complicam a intervenção dos policiais nas ocorrências

\begin{tabular}{l|c|c}
\hline $\begin{array}{l}\text { Fatores ou elementos que mais complicam a intervenção dos } \\
\text { policiais nas ocorrências }\end{array}$ & Freqüência* & $\begin{array}{c}\text { Percentual das } \\
\text { respostas válidas }\end{array}$ \\
\hline Envolvimento de amigos de superiores hierárquicos, na condição de infratores & 97 & 16,7 \\
\hline $\begin{array}{l}\text { Envolvimento de outros policiais militares, sobretudo superiores } \\
\text { hierárquicos, na condição de infratores }\end{array}$ & 95 & 16,3 \\
\hline Envolvimento de policiais civis e (ou) federais, na condição de infratores & 94 & 16,2 \\
\hline Envolvimento de autoridades (políticas e judiciárias), na condição de infratoras & 91 & 15,6 \\
\hline Envolvimento de pessoas com elevado poder aquisitivo e (ou) nível de escolaridade & 73 & 12,5 \\
\hline Pessoas embriagadas ou drogadas & 34 & 5,8 \\
\hline Pessoas confusas ou perturbadas mentalmente & 32 & 5,5 \\
\hline Pessoas armadas (arma de fogo ou arma branca) & 25 & 4,3 \\
\hline Envolvimento de menores infratores & 21 & 3,6 \\
\hline Lutador de artes marciais & 10 & 1,7 \\
\hline Pessoas com baixo nível de escolaridade & 7 & 1,2 \\
\hline Outro (falta de infraestrutura e desigualdade social) & 3 & \\
\hline Rv - Respostas válidas & 582 & 100 \\
\hline Nr - Não responderam & 625 & Ausente \\
\hline Rp - Respostas possíveis(1) & & \\
\hline Fonte: Silva, W. (2009) absoâo, cada entrevistado poderia assinalar até 5 (cinco) alternativas. & & \\
\hline
\end{tabular}

Jr., 2007c). Um tipo de clientelização diversificada, que estimula níveis de autonomização perversa do mandato policial, auferindo rendimentos para as redes sociais e para os negócios criminosos da "proteção". Um tipo de clientelização de mercado, que particulariza a autoridade, privatizando os recursos públicos de segurança.

Tudo isso parece indicar que, na administração das ocorrências policiais, pode-se caminhar de consumidor a 'sobrecidadão', fazendo uso de um direito, de uma prerrogativa funcional, inclusive por extensão e empréstimo de outros, para garantir alguma forma de tratamento privilegiado para poucos, sob um consentimento provisório e silencioso de todos.

A insegurança não costuma ser boa conselheira, principalmente para os PMs, que se veem na delicada situação de indulgência perante uma "autoridade de mais" e de indigência diante de sua "autoridade de menos". Os policiais de rua, tão ou mais inseguros que os cidadãos e sem mui- tas oportunidades para fugir das ocorrências, ouvem a voz do medo de ter encerrada a carreira. Especialmente nas chamadas que envolvem uma autoridade, consideram uma via prudente, para encerrar a ocorrência, chegar (um pouco) depois, na expectativa de que alguma solução razoável chegue antes ou já esteja em curso, necessitando apenas do carimbo oficial da polícia. Como não se sabe ao certo até onde se pode ir com a autoridade policial, não é improvável que se prefira ser um polícia do "depois", que torce, a cada chamada, por uma boa ocorrência: aquela que ninguém viu, que passou despercebida, que pode ser resolvida no local e da qual, até o presente momento, ninguém reclamou.

A expressão muito usual, “O que o(a) Sr(a) quer que eu faça?" parece apontar para o descaminho de uma legitimidade destituída, em desencanto ou em desagrado: obter algum assentimento, revelando a sua precariedade pela aceitação reativa de usar de menos o lugar de 
autoridade policial. Quando isso acontece, temse uma clara manifestação de que "... a autoridade fracassou." (Arendt, 2009, p.129). Fica-se no jogo da sua palavra contra a minha, que desautoriza o policial como instância legal e legítima de mediação entre as partes.

Sabe-se que a construção de legitimidade não está relacionada apenas ao poder hierárquico e funcional, típicos da burocracia, como descreve Weber (1999), ou ao poder formal de polícia, segundo define Meirelles (2009). Ela está alicerçada, principalmente, conforme reflete Arendt (2009), nas relações de confiança que se constroem entre os indivíduos e (ou) entre eles e as instituições, as quais são resultantes de um histórico de representações, expectativas e práticas sociais acerca dos fins, modos e meios do exercício concreto do mandato policial, que se convertem em aceitação e consentimento públicos.

\section{CONSIDERAÇÕES FINAIS}

No Estado Democrático de Direito, tal como nomeamos no Brasil, a Polícia, notadamente a polícia ostensiva, tem papel preponderante na preservação da ordem pública e, sobretudo, na proteção dos cidadãos, com vistas à garantia das liberdades e direitos consagrados nas leis, em especial, na Constituição.

Presente no cotidiano das pessoas durante 24 horas por dia, ela é o órgão mais atuante e mais visível do Estado, que se presta a atender às diversas demandas da população, agindo sempre quando, segundo afirma Bittner ([1974], 1990 p.249), "algo que não deveria estar acontecendo está acontecendo e alguém deve fazer algo a respeito agora", e já! (ênfase no original).

As questões que são demandadas pela população à polícia são de espécies diversas, porque dizem respeito a tudo aquilo que pode ser compreendido como pertencente à ordem pública. Elas vão desde os conflitos, incivilidades e desordens até os pequenos e grandes delitos. Todas apresentam algum nível de risco potencial ou concreto, que exigem, por sua vez, graus distintos de resolutividade e de distribuição gradativa, reversa e redundante de coercitividades. Isto requer dos streetcorner politicians (Muir Jr, 1977), a capacidade discricionária de tomada de decisões acerca dos meios e modos para a produção consentida de soluções razoáveis, todas elas subordinadas aos termos concretos de um mandato policial e às suas dinâmicas de autorização pública e social. Tudo isso para construir um enforcement orientado por - e com sentido de - justiça.

A expectativa social que se tem em relação ao decisionismo policial corresponde ao desafio e à complexidade do lugar de polícia. Particularmente nas sociedades de democracia emergente como a brasileira, em que a produção de obediências consentidas, com o recurso potencial e concreto de força, sob império da lei, segue, ainda, como um "cheque em branco" ou uma "procuração em aberto". Tem-se tanto a subestimação quanto a superestimação do decidir e agir policiais. Essa ambição, para mais ou para menos, quanto ao dever-ser policial, muitas vezes extrapola os limites do que seriam os contornos do seu mandato público, em termos do que se aspira como legal, legítimo, politicamente autorizado, tecnicamente válido e aceito coletivamente. Face à fragilidade dos mecanismos informais de controle e dos dispositivos estatais de regulação, observa-se uma tendência de "pôr na conta da polícia”, ou de sua resolutividade, problemas que ultrapassam a natureza, a função e os papéis propriamente policiais. Isso compromete as próprias alternativas de soluções suficientes, oportunas e apropriadas que qualquer organização de força comedida, as polícias, podem produzir no Estado de Direito.

De uma maneira geral, o trabalho dos policiais que patrulham as ruas, independentemente do tipo de problema que tenham que administrar e (ou) resolver, apresenta-se orientado por um pragmatismo prudente, não apenas em relação às características e circunstâncias que informariam as ocorrências criminais e não-criminais, mas também em relação às formas pelas quais o 
lugar da autoridade policial é, na prática, constituído e negociado.

E é essa a hora da verdade ${ }^{25}$ para a administração da chamada 'paz social' e suas alternativas públicas de provimento de segurança. É precisamente ali, no "calor" das ocorrências, que se pode melhor compreender o modo mesmo com a práxis policial é construída a serviço de qual cidadania, diante de qual Estado, e para afirmação de qual ordem.

Por meio da narrativa sobre os procedimentos operacionais padrão (POPs), revelou-se um modus operandi dos PMs de João Pessoa que, orientado por um saber em ato e em estado de alerta, ocupa-se de conciliar as expectativas conflitantes e, por vezes, paradoxais de legalidade e legitimidade a cada chamada, em cada ocorrência assumida. Nessa busca por uma boa medida, algum agir consentido e que faça sentido para os envolvidos, sob o "espírito da lei", constatou-se que, quando se trata de questões criminais violentas, consideradas de maior gravidade, a tendência dos policiais é dar um encaminhamento formal, conduzindo os envolvidos para a delegacia de polícia, para o devido processo legal. Já nas situações criminais de menor gravidade e não-criminais, que conformam a maior parte do chamamento à polícia, observou-se que os PMs da ponta da linha buscam fazer, desde que não haja risco iminente, uso de expedientes informais e alegais de tomada de decisão, resolvendo no local, harmonizando, conciliando, advertindo ou orientando os envolvidos.

Essa lógica em uso reporta-se ao sensível cotidiano de produção de uma justiça querida como "justa", como já anunciada por Skolnick (1966), mas que, à moda brasileira, mostra-se vulnerável ao acionamento das diversas razões particularistas, evocando o que seria um "direito à diferença" em um fazer-se desigual. E isso de tal maneira, que o exercício legal e legitimo

${ }^{25}$ Para a administração de serviços, que enfatiza a interação entre servidor e cliente, a "hora da verdade" é "qualquer episódio no qual o cliente entra em contato com qualquer aspecto da organização e obtém uma impressão da qualidade de seu serviço.” (Albrecht, 2002, p. 27). da discricionariedade policial torna-se um espaço turvo, que enfraquece a tênue fronteira entre o arbítrio e as arbitrariedades, fazendo com que as interações entre cidadãos policiais e os outros cidadãos tenham como oportunidade e rumo o abuso de, e o desacato à autoridade e ao seu sentido público. Em parte por conta disso, os encontros mais frequentes entre os cidadãos e sua polícia, ou melhor, as chamadas ocorrências criminais de menor potencial ofensivo e as nãocriminais são aquelas que os PMs revelam ser as mais difíceis de resolver, sobretudo quando se tem a presença de alguma autoridade ou de seus "procuradores". É aqui, em uma realidade de baixa visibilidade política e social, permeada de conflitos interpessoais e aberta a níveis significativos de irracionalidade e imprevisibilidade, que se assiste, de forma mais expressiva, ao desafio democrático de fazer valer os princípios da universalidade e da imparcialidade, em um contexto em que se quer ora autoridade de mais, ora autoridade de menos.

A essa altura, fica evidente a questão principal que atravessa todo o texto. Tratou-se de apreciar, através do decisionismo policial paraibano, o concreto do exercício do poder de polícia entre nós. Buscou-se compreender o modo mesmo como a autoridade policial é constituída nas esquinas de uma sociedade que se inscreve entre práticas tradicionais e ideais igualitários, universalistas (Da Matta, 1979).

Viu-se que os sentidos atribuídos ao que seja a autoridade consentida, legal e legítima, são atravessados por apetites oportunos e oportunistas de particularização. Os praças da Paraíba ingressam nas regras do jogo de "desigualizar" os que seriam idealmente iguais, pagando para não ter problemas. Afinal, nunca se sabe ao certo quem, na ocorrência, acontece de querer direito de mais ou de se contentar em ficar com direito de menos.

Na contabilidade perversa que acumula dívidas de cidadania e déficits de autoridade, por meio de desautorizações recíprocas e continuadas, os PMs, que há muito perderam a sua 
inocência política, optam por uma postura reativa, tentando, sempre que podem, chegar (um pouco) depois, para encerrar a ocorrência sem arriscar-se a ver encerrada a sua carreira.

Tal sabedoria, nascida da lida nas ruas com os "humanos direitos" que têm "muitos direitos humanos", põe em relevo o que parece inverter o senso comum acerca do exercício do poder de polícia. Os PMs que patrulham João Pessoa usam bem menos do que se imagina de sua autonomia decisória ou de sua discricionariedade legalmente respaldada. Na prática, o poder do policial tende a ser intencionalmente menor que a amplitude formalmente estabelecida no poder de polícia. Inseguros, política e institucionalmente, quanto aos termos pactuados do seu mandato público, os policiais militares escolhem poder de menos, dramatizando que até podem de mais para sobreviver entre as "carteiradas" que recebem dos seus variados "patrões". Por isso, estão sempre dispostos a passar o bastão das ocorrências para outrem, da forma mais rápida, segura e razoável.

Há o tal do bom senso policial nisso. O padrão policial decisório, extraído dos materiais etnográficos, evidencia estratégias de construção de camadas de legalidade para (re) construir legitimidades, atendendo às expectativas de que alguma "lei" está sendo cumprida, mesmo em situações em que não haveria tradutibilidade normativo-legal. Tem-se como fundamento coercitivo para a abertura de negociação, o encaminhamento para a delegacia, que aparece como um possível ponto de partida e um provável ponto final, frente às esferas de resistência encontradas. A fabricação de camadas de legalidade, pela encenação de que se está fazendo o que manda a lei, permite, no drama informal da condução das ocorrências, reduzir a responsabilização do policial por seus atos discricionários. Nesse jogo de cena entre as partes e o policial, tem-se que, fazendo o que está na lei, o problema passa a ser de quem detém a tal da lei e não de quem faria o seu enforcement. Isso deixa como hipótese, para próximos trabalhos, uma singela questão: o problema do poder de polícia não está propriamente na sua extensão, mas nos modos e meios de seu uso diante de fins nem sempre públicos.

(Recebido para publicação em julho de 2010) (Aceito em setembro de 2010)

\section{REFERÊNCIAS}

ALBRECHT, Karl. Administração de serviços. In: Revolução nos serviços: como as empresas podem revolucionar a maneira de tratar os seus clientes. Trad. Antonio Zoratto Sanvicente. São Paulo: Pioneira, 2002. cap. 2, p. 21-43. Tradução de: At America's service.

ARENDT, Hannah. Que é autoridade. In: Entre o passado e o futuro. Trad. Mauro W. Barbosa. 6.ed. São Pauo: Perspectiva, 2009. cap. 3, p. 127-187. Tradução de: Between past and future.

BAYLEY, David H. Patterns of policing: a comparative international analysis. New Brunswick: Rutgers University Press, 1985. 263 p.

Padrões de policiamento. Trad. Renê Alexandre Belmonte. São Paulo: Edusp, 2001. 267 p. (Série polícia e sociedade, n.1). Traducão de: Patterns of policing: a comparative international analysis.

. Forces of order: policing modern Japan. Califórnia: University Califórnia Press, 1991. 193 p.

BITTNER, Egon. Florence nightingale in Pursuit of Willie Sutton: a theory of the police. In: Aspects of police work. Boston: Northeastern University Press, [1974] 1990. $406 \mathrm{p}$.

BRASIL. Lei $\mathrm{n}^{\circ} 11.313$, de 28 de junho de 2006. Altera os arts. 60 e 61 da Lei 9.099, de 26 de setembro de 1995, e o art. $2^{\circ}$ da Lei 10.259 , de 12 de julho de 2001, pertinentes à competência dos Juizados Especiais Criminais, no âmbito da Justiça Estadual e da Justiça Federal. Diário Oficial [da] República Federativa do Brasil, Brasília, DF, Poder Legislativo. 29 jun. 2006. Seção 1, p.1.

Constituição Federal. Código Penal. Código de Processo Penal Legislação Penal e Processual Penal. Organizacão Luiz Flávio Gomes. 9.ed. rev., ampl. e atual. São Paulo: Revista dos Tribunais, 2007.

Lei $n^{\circ} 5.172$, de 25 de outubro de 1966. Dispõe sobre o Sistema Tributário Nacional e institui normas gerais de direito tributário aplicáveis à União, Estados e Municípios, 2010a. Disponível em: www.planalto.gov.br/ccivil 03/ Leis/L5172.htm. Acesso em: 20 nov. 2010.

CAPEZ, Fernando. Curso de direito penal. 11. ed. rev. atual. São Paulo: Saraiva, 2007. v. 1. Parte geral (arts. $1^{\circ}$ a 120).

DA MATTA, Roberto. Você sabe com quem está falando? Um ensaio sobre a distinção entre indivíduo e pessoa no Brasil. In: Carnavais, malandros e heróis: para uma sociologia do dilema brasileiro. 4.ed. Rio de Janeiro: Zahar, 1979. cap. 4. p. 139-193.

GOLDSTEIN, Herman. Policiando uma Sociedade Livre. Trad. Marcello Rollemberg. São Paulo: Edusp, 2003. 461 p. (Série Polícia e Sociedade, n.9). Tradução de: Policing a free society.

IBGE. Instituto Brasileiro de Geografia e Estatística. Censo 
Demográfico 2000: características da população e dos domićĺlios/resultados do universo. Rio de Janeiro: 2000. 520 p.

. Dados do Censo Demográfico 2010, 2010b. Disponível em: www.ibge.gov. br/censo2010/dados divulgados index.php? uf=25. Acesso em: 20 nov. 2010 .

. Censos Demográficos e Perfil de Informações Básicas, 2010c. Disponível em: www.ibge.gov.br/cidadesat/ topwindow. htm?1. Acesso em: 20 nov. 2010.

KENNETH, David Culp. Discretionary justice: a preliminary inquiry. Baton Rouge: Louisiana State University Press, 1969. $233 \mathrm{p}$

KLOCKARS, Carl B. The idea of police. Beverly Hills: Sage Publications, 1985, 160 p.

LIMA, Roberto Kant de. Polícia, justiça e sociedade no Brasil: uma abordagem comparativa dos modelos de administração de conflitos no espaço público. Revista de Sociologia e Política, Curitiba, n. 13, nov. p. 23-38, 1999.

MANNING, Peter K. Simbolic communication: signifying calls and the police response. Cambridge: The MIT Press, 1988. $309 \mathrm{p}$

MEIRELLES, Hely Lopes. Direito administrativo brasileiro 35.ed. São Paulo: Malheiros Editores, 2009. 839 p.

MISSE, Michel. Mercados ilegais, redes de proteção e organização local do crime. Dossiê Crime organizado. Revista Es tudos Avançados, São Paulo, USP, v. 21, n. 61, 2007. 20 p.

MUIR JR., Willian Ker. Police: streetcorner politicians. Chicago: The University of Chicago Press, 1977. 306 p.

MUNIZ, Jacqueline de Oliveira. Ser policial é, sobretudo, uma razão de ser: cultura e cotidiano da Polícia Militar do Estado do Rio de Janeiro. Rio de Janeiro, 1999. 286 f. Tese (Doutorado em Ciências Políticas) - Instituto de Pesquisas do Rio de Janeiro.,1999.

Discricionariedade e aplicação seletiva da lei na democracia. Revista Ultima Ratio, Rio de Janeiro. Editor Lumen Júris, v. 2, n. 2, p. 97-122, 2008.

; PROENÇA JR, Domício. Bases conceituais de métricas e padrões de medida de desempenho policial. In CARUSO, Haydée; MUNIZ, Jacqueline de Oliveira CARBALLO BLANCO, Antonio Carlos. (Org.). Polícia, Es tado e sociedade: práticas e saberes latino-americanos. Rio de Janeiro: Publit, 2007a. p. 230-280.
Da accountability seletiva à plena responsabilidade policial. In: CARUSO, Haydée; MUNIZ, Jacqueline de Oliveira; CARBALLO BLANCO, Antonio Carlos. (Org.) Polícia, Estado e sociedade: práticas e saberes latino-americanos. Rio de Janeiro: Publit, 2007b. p. 21-73.

. Muita politicagem, pouca política os problemas da polícia são. Dossiê crime organizado. Revista Estudos Avançados, São Paulo, USP, v. 21, n. 61, 14 p, 2007c.

PARAÍBA (Estado). Lei Complementar $n^{\circ}$ 87, de 02 de dezembro de 2008. Dispõe sobre a Organização Estrutural e Funcional da Polícia Militar do Estado da Paraíba e determina outras providências. Diário Oficial do Estado $n^{\circ} 13.970$, João Pessoa, Poder Executivo, 03 dez. 2008. p.1.

PINC, Tânia. Abordagem policial: um encontro (des)concertante entre a policía e o público. Revista Brasileira de Segurança Pública, São Paulo, Fórum Brasileiro de Segurança Pública, v. 1, n. 2, 2007. 195 p.

REINER, Robert. The politics of the police. Toronto: University Toronto Press, 1992. 334 p.

ROVER, Cees de. Para servir e proteger. Direitos humanos e direito internacional humanitário para forças policiais e de segurança: manual para instrutores. Trad. Sílvia Backes e Ernani S. Pilla. Genebra: Comitê Internacional da Cruz Vermelha, 1998.

SILVA, Washington Franca da. Políticas, procedimentos e práticas da polícia ostensiva no atendimento às ocorrências criminais de menor potencial ofensivo e às não-criminais: um estudo sobre a atuação da Polícia Militar da Paraíba em João Pessoa. São Paulo, 2009. 232 f. Monografia (Curso Superior de Polícia) - Centro de Altos Estudos de Segurança da Polícia Militar do Estado de São Paulo, 2009.

SKOLNICK, Jerome H. Justice without trial: law enforcement in democratic society. New York: Macmillan College Publishing Company, [1966] 1994. 312 p.

WADDINGTON, P.A.J. Calling the police. Sydney: Avebury, 1993. $225 \mathrm{p}$

WEBER, Max Economia e sociedade: fundamentos da sociologia compreensiva. Trad. Regis Barbosa e Karen Elsabe Barbosa. Brasília: UnB, 1999. p. 529. Tradução de: Wirtschaft und Gesellschaft: Grundriss der verstehenden Soziologie.

WILSON, James Q. Varieties of Police Behavior. The Management of law and order in eight comunities. New York: Atheneum, 1968. 309 p. 
POLICE MANDATE IN USE: making decisions on the streets of João Pessoa

\section{Jacqueline de Oliveira Muniz Washington França da Silva}

This article turns to the modus operandi of the police beat of public order officers of the Military Police of Paraíba, directing its focus on what is the "standard operation" of MPs who do the "ostensive policing" in Joao Pessoa.

It follows the point of view of these officers on their discretionary practice in responding to non-criminal and criminal incidents, trying to understand how the public office mandate works on the streets and, therefore, through which ways and means the police authority is concretely exercised for the "purposes" for which it is called to act.

KEYWORDS: police mandate, discretionary power, military Police, conflict management, use of force.
MANDAT DE POLICE DANS LA PRATIQUE: prise de décisions dans les rues de João Pessoa

\section{Jacqueline de Oliveira Muniz Washington França da Silva}

Cet article traite dudit modus operandi des patrouilleurs de l'ordre public de la Police Militaire de l'état de Paraíba, vu en particulier sous l'angle de ce que l'on appelle "le modèle opérationnel" des PMs (Policiers Militaires) qui s'occupent de la "surveillance ostensive" à João Pessoa. On part du point de vue de ces policiers par rapport à leur pratique discrétionnaire dans le cadre des affaires criminelles et non criminelles. On essaie de comprendre comment la police exerce sa fonction dans les rues et, par conséquent, de savoir quels sont les moyens utilisés et de quelle manière s'exerce concrètement l'autorité policière pour atteindre les "buts" auxquels sont action se destine.

Mots-CLÉS: mandat de police, pouvoir discrétionnaire, police militaire, administration de conflits, utilisation de la force.

Jacqueline de Oliveira Muniz - Antropóloga. Doutora em Ciência Política pelo IUPERJ/ UCAM. Professora do Mestrado em Direito da Universidade Cândido Mendes e da Graduação Tecnológica em Segurança e Ordem Pública (TECSOP) da Universidade Católica de Brasília - UCB. Integra o Grupo de Estudos Estratégicos - GEE/Coppe/UFRJ e conselheira do Fórum Brasileiro de Segurança Pública. Atua na área de Antropologia e Ciência Política, com ênfase em estudos sobre Segurança Pública e Justiça Criminal, tendo publicado, entre outros, artigo no livro Comércio e segurança pública no estado do Río de Janeiro (Rio de Janeiro: FECOMERCIO-RJ, 2010 (coletânea de vários autores) e editado (com Haydée Carusoe Antonio Carlos Blanco) a coletânea Polícia, Estado y Sociedad: prácticas y saberes Latinoamericanos. (Rio de Janeiro: Publit Seleções Editoriais, 2007), entre outros artigos.

Washington França da Silva - Oficial da Polícia Militar do Estado da Paraíba, especialista em políticas públicas de justiça criminal e segurança pública e associado do Fórum Brasileiro de Segurança Pública. 